\title{
Portfolio balance effects of the SNB's bond purchase program
}

Andreas Kettemann and Signe Krogstrup

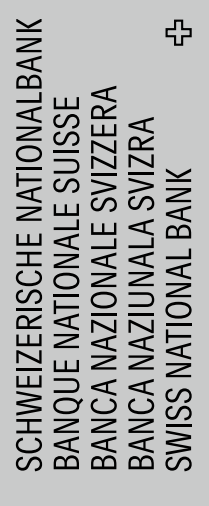


The views expressed in this paper are those of the author(s) and do not necessarily represent those of the Swiss National Bank. Working Papers describe research in progress. Their aim is to elicit comments and to further debate.

\section{Copyright ${ }^{\odot}$}

The Swiss National Bank (SNB) respects all third-party rights, in particular rights relating to works protected by copyright (information or data, wordings and depictions, to the extent that these are of an individual character). SNB publications containing a reference to a copyright ( $\odot$ Swiss National Bank/SNB, Zurich/year, or similar) may, under copyright law, only be used (reproduced, used via the internet, etc.) for non-commercial purposes and provided that the source is mentioned. Their use for commercial purposes is only permitted with the prior express consent of the SNB.

General information and data published without reference to a copyright may be used without mentioning the source.

To the extent that the information and data clearly derive from outside sources, the users of such information and data are obliged to respect any existing copyrights and to obtain the right of use from the relevant outside source themselves.

\section{Limitation of liability}

The SNB accepts no responsibility for any information it provides. Under no circumstances will it accept any liability for losses or damage which may result from the use of such information. This limitation of liability applies, in particular, to the topicality, accuracy, validity and availability of the information.

ISSN 1660-7716 (printed version)

ISSN 1660-7724 (online version)

๑ 2013 by Swiss National Bank, Börsenstrasse 15, P.0. Box, CH-8022 Zurich 


\title{
Portfolio balance effects of the SNB's bond purchase program*
}

\author{
Andreas Kettemann ${ }^{\dagger} \quad$ Signe Krogstrup ${ }^{\ddagger}$
}

February 25, 2013

\begin{abstract}
This paper carries out an empirical investigation of the impact on bond spreads of the announcement, purchases and exit from the SNB's bond purchase program in 2009-2010. We find evidence in favor of a narrowing yield spread of covered bonds as a result of the program. The effect materialized in the days following the announcement of the SNB's intention to buy bonds issued by private sector borrowers, as markets learned that the SNB was buying covered bonds. The specification of the bond spreads used allows us to identify this effect as a discounted portfolio balance effect of the expected purchases, as distinct from policy signalling. In contrast, we find no evidence of a further effect of the actual purchases and subsequent sales on bond spreads.
\end{abstract}

\section{JEL: E5; G1}

Keywords: portfolio balance; credit spread; corporate spread; unconventional monetary policy; central bank asset purchases; credit easing; zero lower bound

*Thanks to Katrin Assenmacher, Jean-Pierre Danthine, Sebastien Kraenzlin, Christopher Neely, Angelo Ranaldo, Sandro Streit and participants at the SNB brownbag seminar, the University of Basel Research Seminar, the SGVS Annual Conference 2012, and the Federal Reserve Day-Ahead Conference in San Diego, January 2013, for valuable comments and suggestions. Thanks also to Markus von Allmen and Marco Nigg for helpful datawork. The views represented in this paper reflect those of the authors and not necessarily those of the Swiss National Bank.

${ }^{\dagger}$ Kettemann: University of Zurich, Department of Economics, Mühlebachstrasse 86, 8008 Zürich, Switzerland. Email: andreas.kettemann@econ.uzh.ch.

${ }^{\ddagger}$ Krogstrup: Swiss National Bank, Börsenstrasse 15, 8022 Zürich, Switzerland. Phone: +41 446313813. Email: signe.krogstrup@snb.ch. 


\section{Introduction}

As policy rates were reduced to the lower bound in early 2009 in many western countries, and the economic outlook called for further monetary stimulus, a number of central banks resorted to using alternative monetary policy tools. Among these were outright asset purchases. The Federal Reserve engaged in large scale asset purchases, in several rounds, starting in late 2008. The Bank of England carried out purchases of Gilts, also in several rounds. The Bank of Japan was engaged in government bond purchases even before the Financial Crisis, and has continued to purchase bonds throughout the crisis period. The ECB has also purchased sovereign bonds, although on a smaller scale and with a different objective. What is less well known is that the Swiss National Bank (SNB) has also engaged in asset purchases as an unconventional policy measure. In March 2009, the SNB announced its intention to buy bonds by private issuers, after which it bought covered and non-bank corporate bonds directly from the markets. The SNB's bond purchase program is unique in international comparison in that the program has already been exited. Without announcement, the bonds were discretely sold off in 2010. This paper looks at the effect of the announcement of the program, and exploits the variation in the Swiss data on bond purchases and sales to carry out an empirical investigation and identification of the effects of these on Swiss covered and corporate credit spreads.

Central bank asset purchases are argued to affect long-term interest rates mainly through two channels. The first is the policy signalling channel, which suggests that a central bank's engagement in asset purchases independently signals something to market participants about the central bank's intended future policy stance, which in turn affects expected future policy rates. The second is the portfolio balance effect, which suggests that under certain assumptions about market segmentation, the effect of an asset purchase induced change in the relative supply of the purchased asset can affect its price. A large and very active empirical literature investigates the importance of the difference channels of transmission of currently active asset purchase programs. Recent examples for the US and UK programs include Gagnon et al. (2011), Hamilton and Wu (2012), Neely (2010) and Joyce et al. (2011). Preliminary investigations of the ECB's securities markets program are discussed in Manganelli (2012). While this literature has made substantial advances in estimating the likely effect of central bank purchases on the yields of the purchased assets, it has proved harder to empirically identify the different channels through which this effect has come about (Bauer and Rudebusch (2011), Christensen and Rudebusch (2012)). The predominant approach to identifying the different channels has been to estimate term structure models, noting that portfolio balance effects should affect only term premia, whereas policy signalling effects should affect only the risk neutral part of interest rates (i.e. expected future short rates). However, the outcome of term structure model estimation is uncertain and highly dependent on the specific model estimated.

We contribute to this literature by studying the effects of the SNB bond purchase program on bond spreads. In March 2009, the SNB announced that it would be purchasing bonds issued by private borrowers. The announcement was part of a broader package of measures to address the adverse economic circumstances at the time, including more provision of liquidity and foreign exchange interventions. The bond purchases took place during the spring and summer of 2009. The purchased bonds were subsequently discretely sold back into the markets during 2010. This is, to the knowledge of the authors, the only central bank bond purchase program initiated as an unconventional policy measure during the financial crisis 
which has been exited.

As only one announcement of the program was made, and many other policy initiatives were announced by the SNB at the same occasion, we are not able to identify potential policy signalling effects of the announcement of this program. Instead, we are able to identify portfolio balance effects. Data for the Swiss bond market allows us to compute a modelindependent measure of the variation in the issuer-specific term premium for the categories of bonds purchased by the SNB. Portfolio balance effects affect the issuer specific term premium, while policy signalling effects do not. We identify the portfolio balance effects by matching the variation in the issuer specific term premium with the announcement and time profile for the SNB bond purchases.

We find evidence of a significant fall in the term premium on covered bonds following the announcement and implementation of the SNB bond purchase program, suggesting the presence of expected or actual portfolio balance effects. The effect materialized in the days following the announcement of the program, as the markets were learning that the SNB was buying covered bonds. The purchases of covered bonds during the rest of 2009 did not exhibit additional systematic significant effects on the covered bond spread in the daily frequency. We also find no effects on bond spreads of the unannounced exit from the program in 2010 at the daily frequency. One interpretation is that markets fully discounted the expected effect of the purchases and subsequent sales in the days following the onset of the program. This would have required that markets correctly forecasted the SNB's intended purchases and sales, both in terms of volumes and dates, which is unlikely. It is also possible that portfolio balance effects of the actual purchases did occur, but not systematically, and at a different frequency than the daily one. In this case, our data and econometric methods would not allow us to pick it up. Another interpretation is the possible presence of reverse causality from bond spreads to SNB bond purchase decisions. In lack of good instruments, it is very difficult to deal econometrically with this problem. Finally, it is possible that only perceived or expected (as opposed to actual) portfolio balance effects exist, and that these only materialize if and when the market is aware of the central bank's actions.

The paper proceeds as follows. Section 2 discusses how central bank purchases of Swiss corporate bonds should be expected to affect credit spreads, and how we identify these effects empirically. Section 3 describes an index of the credit spread for sub-categories of bonds in the Swiss bond market. This index allows us to isolate the exact component of the term premium which should be expected to be affected by central bank purchases. Section 4 presents the data and conducts an event analysis based on graphical evidence, while Section 5 outlines the econometric approach and provides regression results. The final section concludes. Appendix provides details on the data, and a copy of the press release which announced the SNB bond purchase program.

\section{The SNB bond purchase program and identification of its impact}

At 14:00 o'clock on 12 March 2009, in connection with its regular quarterly monetary policy assessment, the SNB announced that it would engage in purchases of bonds issued by 
private sector borrowers, in order to bring about a relaxation of conditions in the capital markets, thereby improving monetary transmission. In later speeches of SNB board members, the policy was also referred to as credit easing, with the aim of reducing risk premia in capital markets. The text of the press release shows that a number of other unconventional policy measures were announced at the same occasion. The target for the 3M CHF Libor was reduced to 0.25 percent, which was considered the effective zero lower bound, and the targeted Libor fluctuation band was narrowed. More repo operations with longer maturities were announced. Moreover, the SNB announced that it would engage in foreign exchange interventions to prevent further exchange rate appreciation.

No information was given about the size of the bond purchase program, nor was any information given on which types of privately issued bonds would be purchased. The markets thus had to learn from the subsequent actions taken by the SNB. The SNB started to purchase covered bonds immediately, i.e. right after 14:00 o'clock on 12 March 2009. During the first weeks after the announcement, the SNB exclusively bought mortgage backed covered bonds. Covered bonds, or "pfandbriefe", are bonds issued under a specific law for this purpose, by one of two institutions, the Pfandbriefbank and the Pfandbriefzentrale. The purpose is to provide funding for banks' issuance of mortgages. The institutions are owned by the issuing banks. Backed by mortgages pledged by banks, the two institutions issue mortgage covered bonds which are sold in the markets. The proceeds of these bond sales are then lent on to the banks which have pledged the mortgages. At issuance, covered bonds have at least three years to maturity, but there are no upper constraint on the length of the maturity. In 2009, the average maturity of outstanding covered bonds fluctuated between 4.5 and 5 years, and its outstanding volume amounted to about CHF 64 bln.

About three weeks into the SNB bond purchase program, on 6 April 2009, the SNB commenced purchases of non-bank corporate bonds in addition to continuing the purchases of covered bonds. Non-bank corporate bond purchases remained a small part of overall purchases throughout the program. The vertical line in Figure 1 shows the announcement and date of first purchases on 12 March 2009, and the red and black lines show purchases of covered and corporate bonds respectively.

The SNB's purchases of covered and corporate bonds took place at different times of day during the purchase period, and the purchases continued until early July. No further bonds were purchased after July. The purchases were officially discontinued in September 2009, and the program was announced as completed in December 2009.

The program was exited as the bonds were sold back into the market between March and August 2010. This was a period of falling risk aversion and high demand for assets denominated in Swiss francs, notably Swiss bonds. The profile for the bond sales is depicted in Figure 2. The exit was not announced. The sales were carried out anonymously, and remained largely unnoticed. The first piece of information as to the fact that the SNB was selling off its bonds came in late August 2010 with the release of its monthly balance sheet statistics (monthly bulletin). At this time, nearly all the bonds had been sold off.

At the height of the program, the SNB had purchased a total of about CHF 3 billion worth of bonds, or about $0.5 \%$ of Swiss GDP, which is small relative to for example the Fed- 


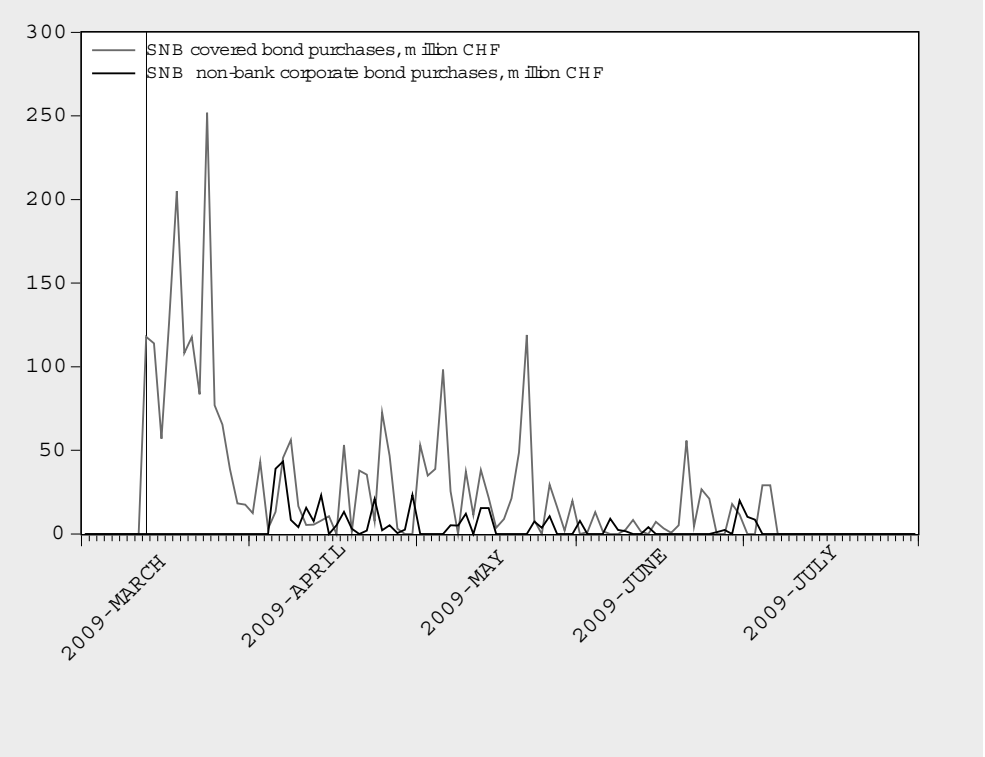

Figure 1: SNB Purchases of bonds issued by private borrowers, in million CHF. 2009

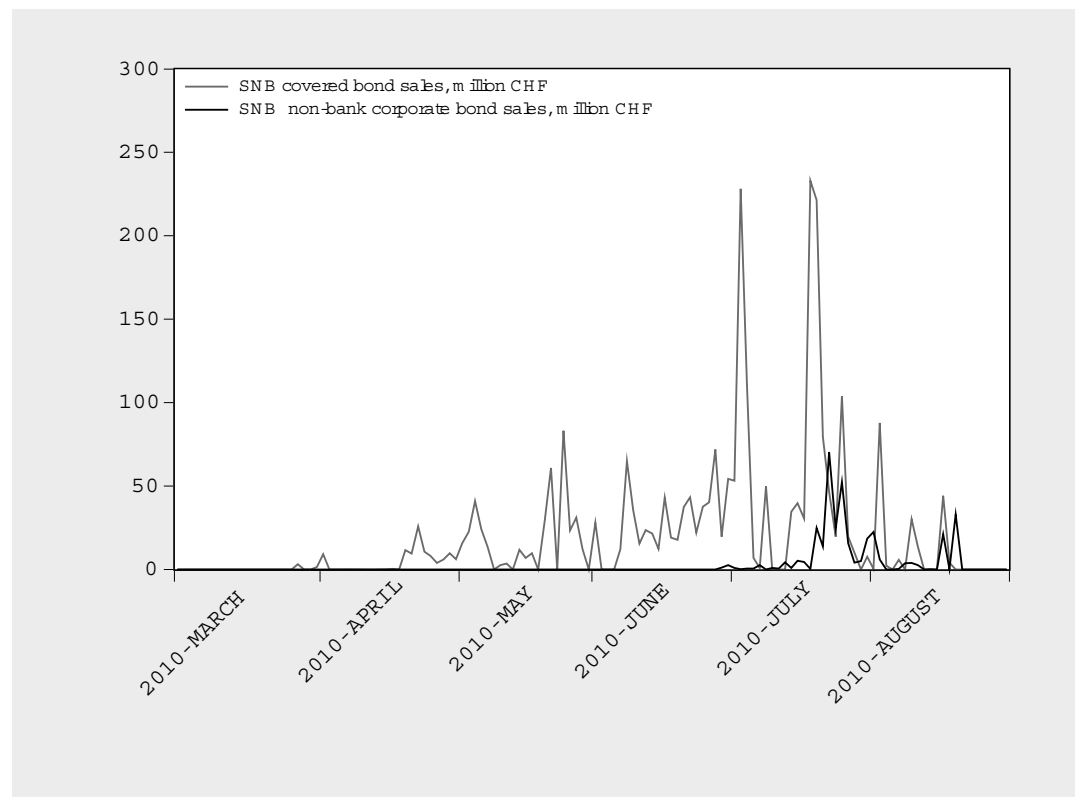

Figure 2: SNB sales of bonds issued by private borrowers, in million CHF. 2010 
eral Reserve asset purchase programs (the total assets purchased by the Federal Reserve now exceed $10 \%$ of GDP). The program was not small relative to the size of the Swiss bond market, however. At the end of 2009, covered bonds on the balance sheet of the SNB amounted to about $5 \%$ of the total market volume of covered bonds at that time, $20 \%$ of gross new issuance and $100 \%$ of net new issuance of covered bonds in the Swiss market in 2009. The corporate bond purchases were less substantial, both in absolute and in relative terms.

How should we expect the SNB's announcement and subsequent bond purchases to have affected private sector bond yields? The yield of a bond can be written as consisting of a risk neutral part as given by expected future short interest rates, and a term premium, according to:

$$
i_{t, j}^{m}=R N_{t}^{m}+T P M_{t}^{m}+T P I_{t, j}^{m}
$$

where $t$ is time, $j$ is the specific issuer, and $m$ is maturity. $R N_{t}^{m}$ is the risk-neutral part of the interest rate. The term $T P M_{t}^{m}$ is a macro risk premium, capturing for example uncertainty regarding the growth and inflation outlook, or changes in overall risk aversion. In contrast, $T P I_{t, j}^{m}$ is an issuer specific risk premium, which depends on issuer specific risks such as the risk of default of the issuer in question, risk aversion, and preferred habitat. Whereas per definition, $T P I_{t, j}^{m}$ differs across issuers, $R N_{t}^{m}$ and $T P M_{t}^{m}$ are the same for all bonds in the country in question.

The effect of the bond purchase program on bond yields can be divided into two broad categories, namely the policy signaling effect and the portfolio balance effect discussed in the introduction. First, the SNB bond purchase program could have signalled to the markets something about how the SNB perceived the economic situation and prospects. In turn, the program would have affected the market view of how the SNB intended to set short term interest rates in the future. Such changes in expected future policy rates would affect $R N_{t}^{m}$. Policy signalling effects could have occurred both at the announcement of the policy, and when the subsequent outright purchases took place, as both types of instances could have contained separate new information.

Second, portfolio balance effects would arise because central bank purchases of bonds directly from the markets would reduce the remaining supply of such bonds in the market. Private portfolios would hence have to adjust. All else equal, a reduction in the supply of a bond would tend to increase the price of that bond relative to the prices of other assets according to theories of portfolio balance (see for example Tobin (1965), Hamilton and Wu (2012) or Vayanos and Vila (2009)). The portfolio balance effect would affect the $T P I_{t, j}^{m}$ part of the yield. It is possible that the $T P I_{t, j}^{m}$ of close substitutes to the bonds purchased by the central bank would also be affected through substitution effects.

The portfolio balance effect can occur at announcement and when the actual purchases take place, depending on the level of information that markets have at each of these types of events. If market participants know in advance the size of the purchases, the timing and the type of bonds to be purchased, it is reasonable to assume that some, if not all, of the portfolio balance effects will happen instantly, as markets discount the expected change in the price. However, in the case of the SNB bond purchase program, and as opposed to the 


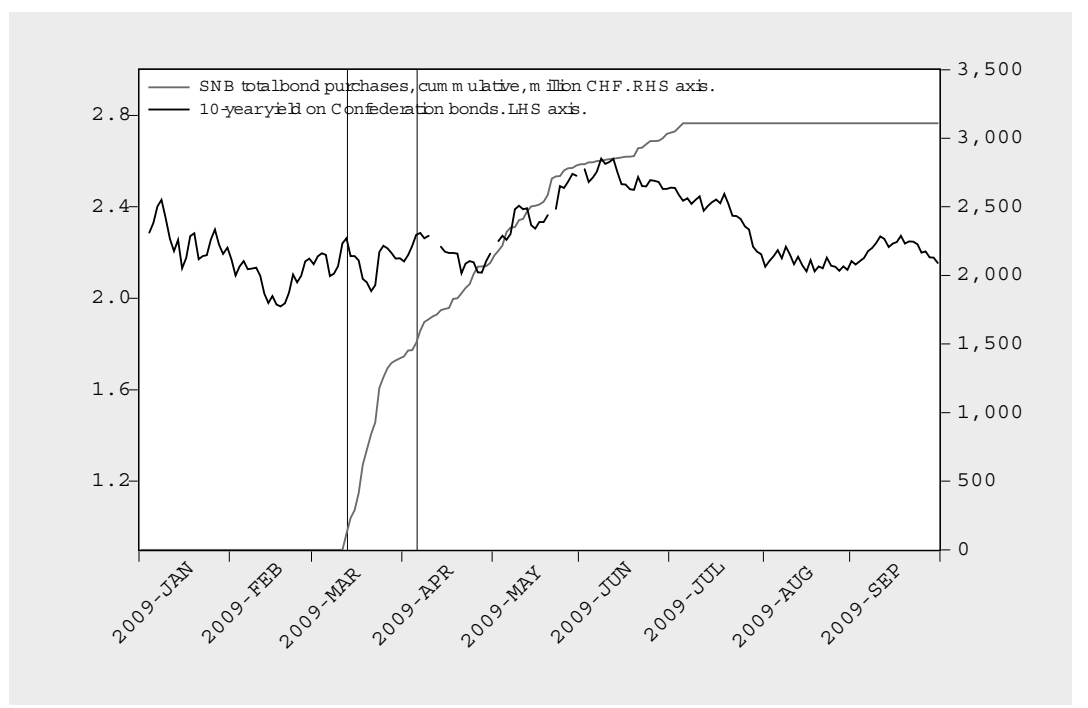

Figure 3: The SNB bond purchases and the 10-year yield on Confederation bonds

Federal Reserve and Bank of England programs, this information was not relayed with the announcement of the program, nor at any later stage prior to the termination of the program. Markets were hence left to infer from the subsequent actions of the SNB which types of bonds would be purchased and how much. Portfolio balance effects could hence have occurred both at announcement time, and in connection with the subsequent actual purchases.

Separating the effect of the program into a policy signaling effect which affects risk-neutral rates only, and a portfolio balance effect which affects the term premium only, is of course a convenient simplification which facilitates the empirical analysis. A few potential complications should be noted, however, as they will have to be kept in mind for the specification of the baseline regression and controls.

First, the news that the announcement provided to the markets about the future economic outlook and the seriousness of the situation could also have affected the uncertainty about expected future growth and inflation outcomes, which in turn would affect TPM $M_{t}^{m}$. This could in turn have increased market risk aversion, which would have affected bonds as a function of their level of risk, and hence, $T P I_{t, j}^{m}$. Moreover, if markets adjusted their expectations of the economic outlook when the bond purchase program was announced, then this could have affected the expected default risk of certain borrowers more than others, in turn affecting $T P I_{t, j}^{m}$. These effects through risk aversion and expected default risk have to be kept in mind, as we will need to control for them in our regressions.

The purchase program could also have affected the market liquidity of the purchased bonds, which in turn could have affected their attractiveness and hence price. This market liquidity effect (to be distinguished from the liquidity effect of higher bank reserves) would also affect the issuer specific term premium of the bonds, $T P I_{t, j}^{m}$. We take this possible market liquidity effect into account in the empirical specification by controlling for a measure of market liquidity specific to the categories of the purchased bonds. 
Finally, any unsterilized asset purchases by a central bank increases banks' reserves and hence the money supply. In turn, more bank reserves could increase the overall demand for assets from banks, which in turn would tend to increase the price of assets, as argued in Krogstrup et al. (2012). The effect is referred to as a liquidity effect in the traditional macro literature (see for example Cochrane (1989)). All else equal, the liquidity effect should not discriminate between assets in banks' portfolios. It could hence reduce $T P M_{t}^{m}$, but should not necessarily affect the issuer specific term premium $T P I_{t, j}^{m}$. One exception is worth mentioning. Empirically, liquidity effects have mainly been found in the yields of highly liquid and safe bonds such as government bonds. It could hence be that the liquidity created by the bond purchases would have had the effect of reducing Confederation bond yields more than the yields of other bonds. If so, this would not be a problem for our identification strategy here, as explained in Section 5.2. Note that there is no reason to expect liquidity effects of the bond purchase program itself to have been important in Switzerland, given the relatively small size of the program, as well as the high level of bank reserves already in the system at this time due to other unconventional policy measures. Just as is the case for the portfolio balance effect, liquidity effects could occur at announcement as well as at the actual bond purchase times, depending on the market's level of information at these events. With a few short-lived exceptions, Confederation bond yields did not generally fall during the period in which the SNB was buying bonds, see Figure 3.

The discussion of the different effects of the bond purchase program implies that if we isolate $T P I_{t, j}^{m}$ in the data, and associate it with the announcement time of the SNB bond purchase program as well as the dates of the subsequent actual bond purchases, and control for changes in risk aversion, market liquidity and expected default risk, then any remaining significantly negative correlation with the bond purchases or with the announcement of the bond purchase program should indicate portfolio balance effects.

\section{The credit spread as a measure of the issuer specific term premium}

Based on Equation (1), we compute the issuer specific term premium as the spread of the yield on any individual bond over the yield on the corresponding maturity Confederation bond.

$$
\begin{aligned}
C S_{t, j}^{m} & =i_{t, j}^{m}-i_{t, \text { conf }}^{m} \\
& =T P I_{t, j}^{m}-T P I_{t, \text { conf }}^{m}
\end{aligned}
$$

We then assume that $T P I_{t, C o n f}^{m}$ is orthogonal to the SNB's bond purchases. As discussed above, liquidity effects of the bond purchases could affect the Confederation bond specific term premium, but such an effect would only bias our results downward. Apart from liquidity effects, the assumption of an orthogonal $T P I_{t, C o n f}^{m}$ is reasonable in light of the liquid market for Confederation bonds and the very low default risk of these bonds. In order to get a smooth series for the credit spread over time, we take a weighted average of these bond specific term premia across categories of bonds traded in the Swiss bond market, to get credit indices for covered bonds, domestic non-bank corporates, cantonal bonds and bank bonds. 


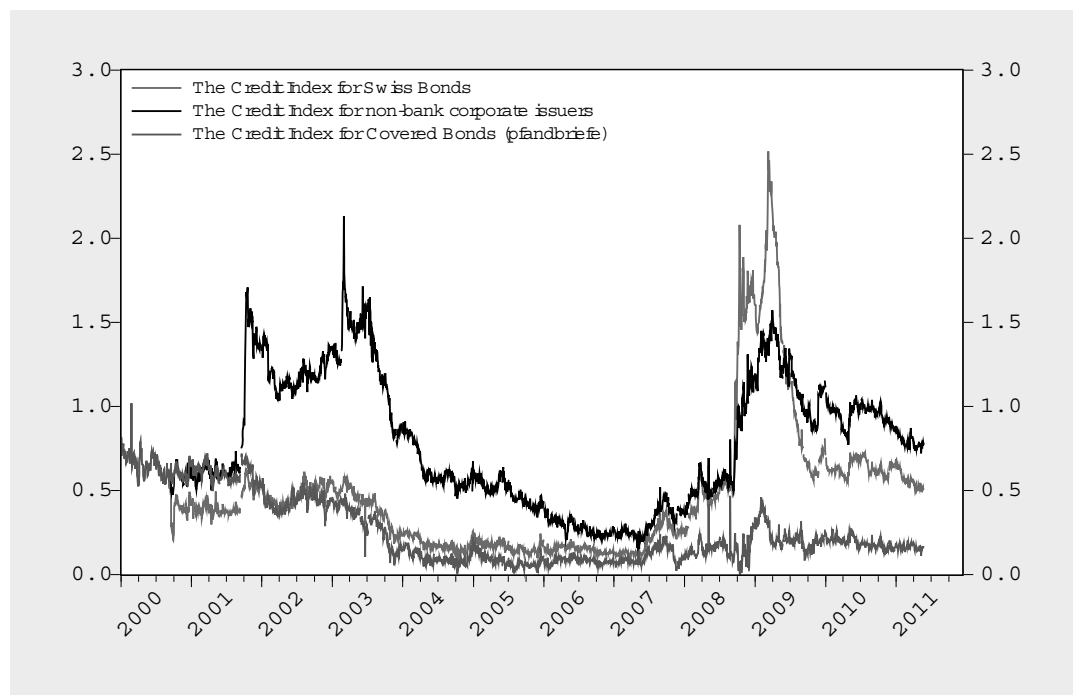

Figure 4: The credit index for total, covered and corporate bonds

The first two are the focus of this analysis. The latter two indices are used for comparison, as substitutes for a counterfactual.

The credit indices are derived from individual bond yield-to-maturity spreads over Swiss Confederation bonds of the same maturity (the latter interpolated using a spline), aggregated according to the emission volume of the bond in question, and across all maturities. ${ }^{1}$ The individual bond data are derived from the SNB internal database on Swiss bond market features, which in turn in based on data available from the SIX Swiss Exchange. Both indices are based on a sufficiently large set of observations for every point in time to be representative of overall market conditions. The resulting series for covered and corporate bonds, as well as an index comprising all bonds in the Swiss bond market, are depicted in Figure 4.

\section{Event study approach}

We start with an investigation of the announcement, onset and purchase period in the spring and summer of 2009, and finish up with an inspection of the exit in 2010.

\subsection{The announcement and the bond purchases in 2009}

Figure 5 depicts the covered spread together with the SNB bond purchases from December 2008 to September 2009. The two vertical lines in the Figure denote, first, the announcement of the program and beginning of the covered bond purchases on Thursday 12 March, and second, the onset of the more moderate non-bank corporate bond purchases on Monday 6 April 2009. The covered spread on covered bonds at first did not react to the announcement.

\footnotetext{
${ }^{1}$ The averaging over different maturities could cause the credit index to be correlated with the average timeto-maturity in the market. However, the mean time-to-maturity shows little variation over time and is never significant in the various regressions we conduct.
} 


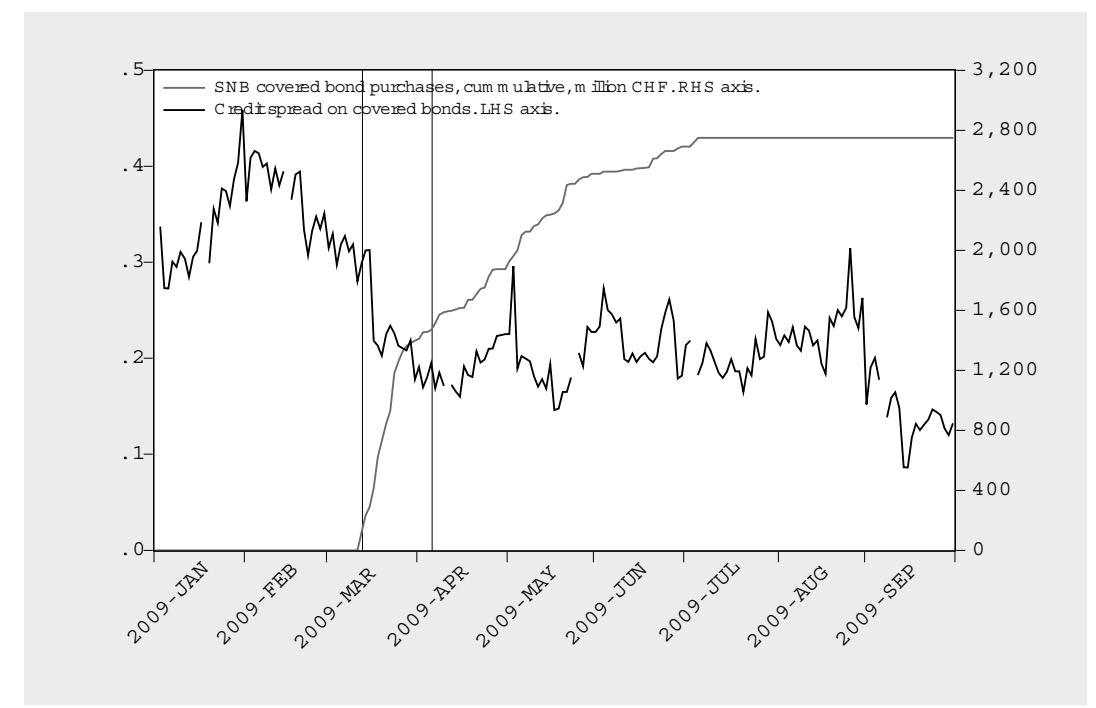

Figure 5: Daily covered bond credit spread and the SNB covered bond purchases in 2009, levels

Zooming in on the months of March and April of 2009, Figure 6 shows that the covered spread remained steady between the morning of Thursday 12 March and the morning of Friday 13 March (the data underlying the calculation of the spread is observed between 9am and 11am in the morning). The spread also largely did not move between the morning of Friday 13 March and Monday 16 March. A drop of about 10 basis points then occurred between the morning of Monday 16 March and the morning of Tuesday 17 March. The spread fell further between 17 March and 19 March 2009, and largely continued to drop in the weeks after the onset of the covered bond purchases.

How unusual is a 10 basis point daily change in the covered credit spread? Figure 7 shows the daily changes in the covered credit spread between 2002 and 2011. Daily changes falling within the shaded area are within 10 basis points. The Figure shows that since 2002, only seven days saw changes in the covered credit spread which were larger than 10 basis points. 10 basis points is five times the standard deviation of the spread over the sample period. Figure 7 shows that the standard deviation of changes in the spread has been time varying, and that it seems to have been elevated during the time period of the SNB bond purchases. Still, during the year between mid-2008 and mid-2009, there were only three observations of daily changes in covered spread which exceeded 10 basis points. ${ }^{2}$ A 10 basis point change in the spread is unusual, even during the crisis period of elevated volatility.

Figure 8 shows that there was no visible effect of the SNB announcement on 12 March 2009 on corporate bond spreads, nor were there any noticeable reactions in two to three days afterwards. Instead, the corporate credit index started declining on 2 April 2009, a few days before the SNB started outright purchases of non-bank corporate bonds on 6 April. From pure visual inspection, however, it is not clear that this decline was related to the bond purchase program. ${ }^{3}$

\footnotetext{
${ }^{2}$ To allow for time-varying variation, we estimate a $\operatorname{GARCH}(1,1)$ model as a robustness test in Section 5.2

${ }^{3}$ A speech was given by the president of the SNB governing board on 2 April 2009, in which the intentions of
} 


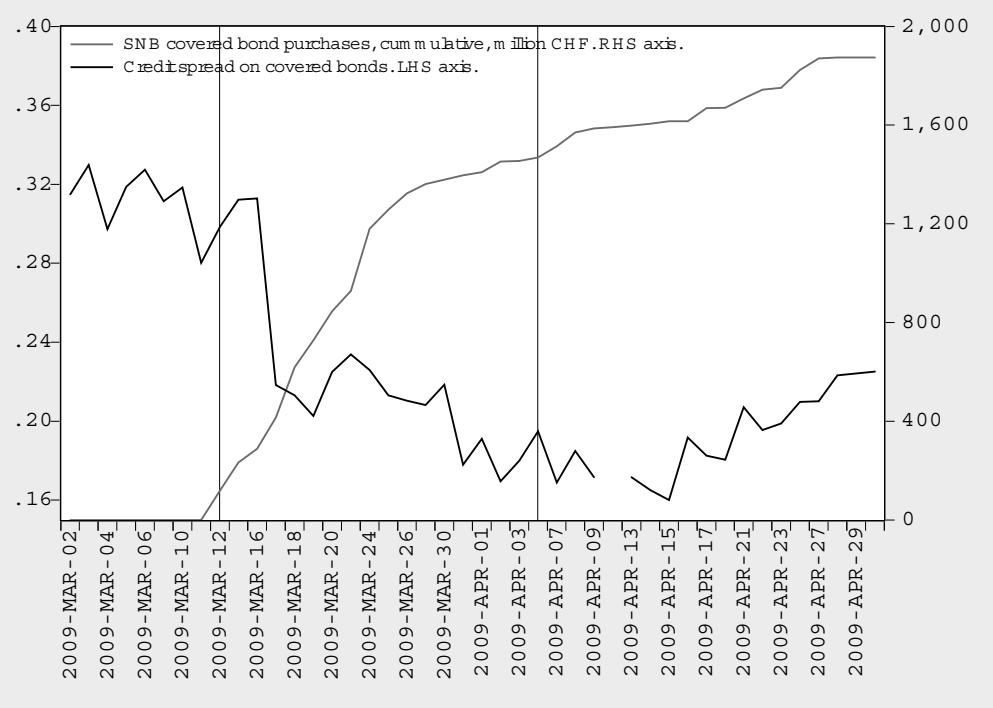

Figure 6: Daily covered bond credit spread and the SNB covered bond purchases in 2009, levels

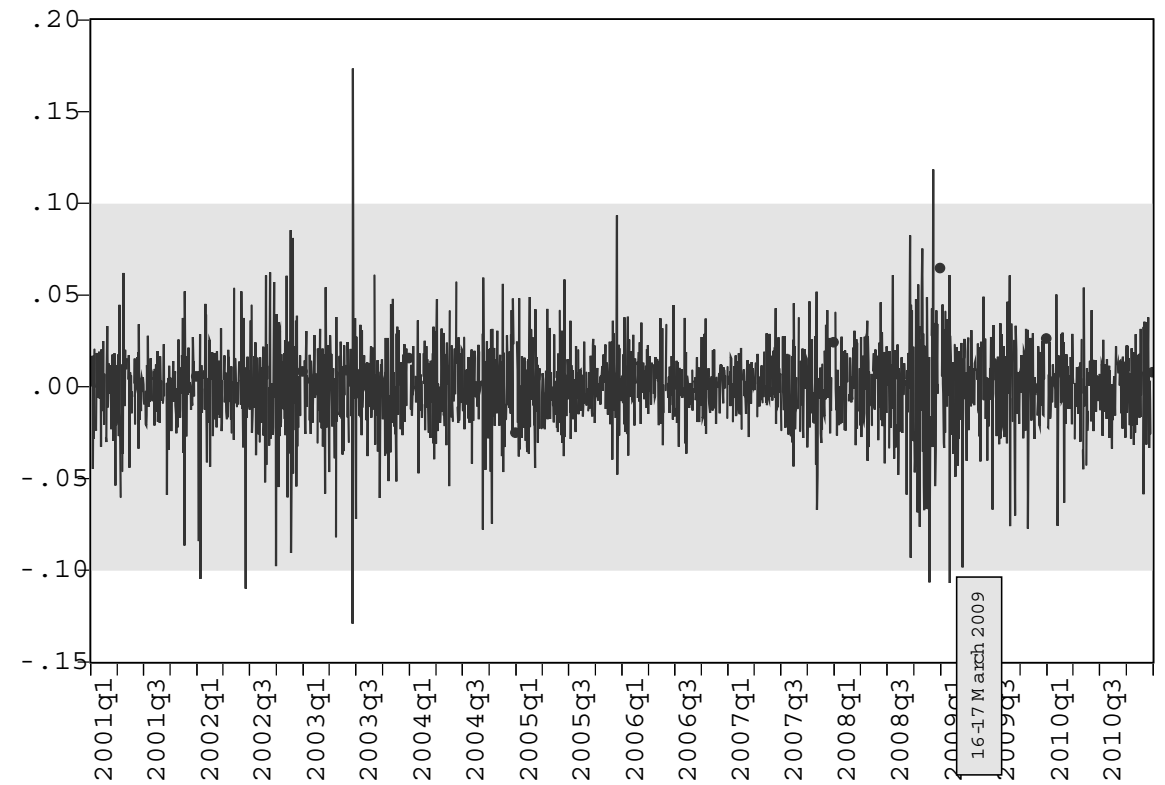

Figure 7: Daily changes in the covered credit index, 2002 - 2011 


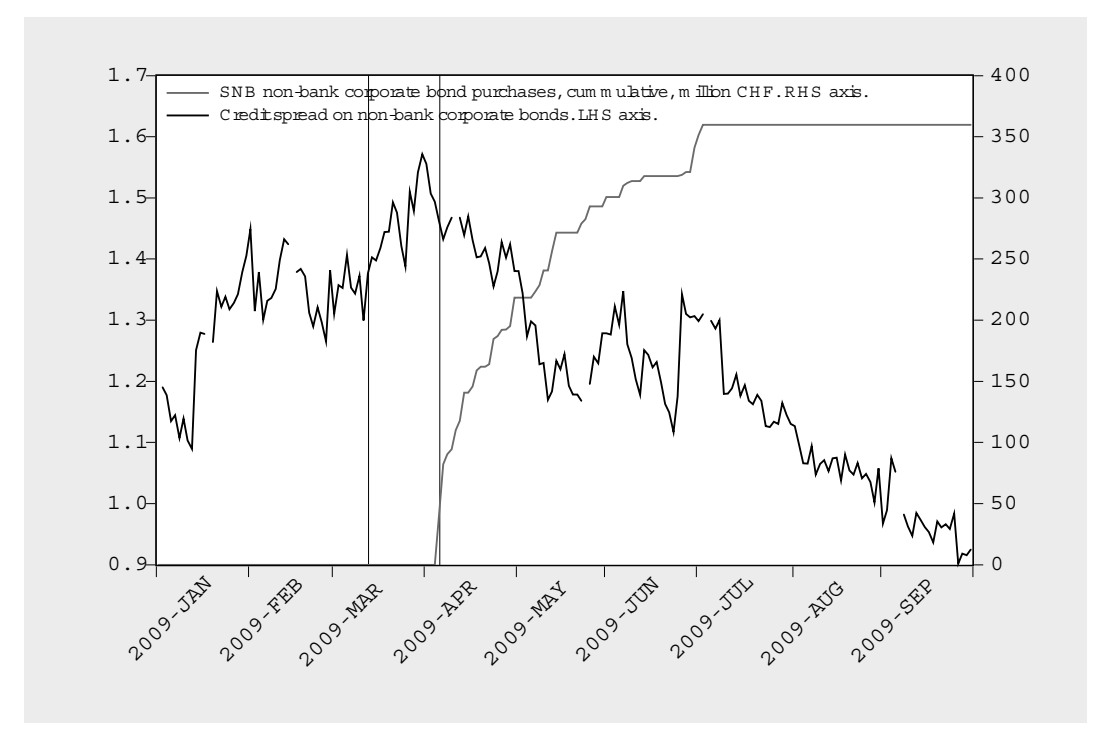

Figure 8: Daily non-bank corporate credit index and cumulated SNB non-bank corporate bond purchases in 2009, levels

Figures 9 and 10 depict the credit indices of two other categories of bonds which were not purchased by the SNB, together with the SNB bond purchases. Inspecting the movements of these spreads around the time of the announcement of the bond purchase program allows us to assess whether any general movements in bond spreads took place during this period. If so, it would suggest that something other than the SNB bond purchase program would be responsible. Just as for corporate bond spreads, neither the spreads for cantonal bonds nor the spreads for bank bonds were falling in the days following the SNB announcement. On the contrary, spreads for other bond categories increased. The strong fall in covered bond spreads is hence particular to covered bonds rather than a change in overall bond market conditions or sentiment.

Figure 11 shows the movement of 10-year Confederation bond yields around the time of the announcement of the SNB bond purchase program. Yields dropped in the days after the announcement, which could reflect changes in all three components of the yield. The drop suggests that the fall in the credit spread on covered bonds in the days after the announcement came in spite of a drop in risk free rates, i.e. covered bond yields fell even more than risk free yields.

Allowing for a window of three days for an announcement effect to happen is important in the present study, as market participants were not informed of the SNB's precise intentions, and hence needed time to learn by observing the actions of the SNB. But the wide window clearly increases the risk that other news and events could have been the cause of the movements in the spread. We have hence carefully read through the Swiss financial press on all days between 12 and 17 March 2009 in search of candidate news and events that could have

the bond purchase program were discussed. Whether or not this information was important for the spread is difficult to assess. 


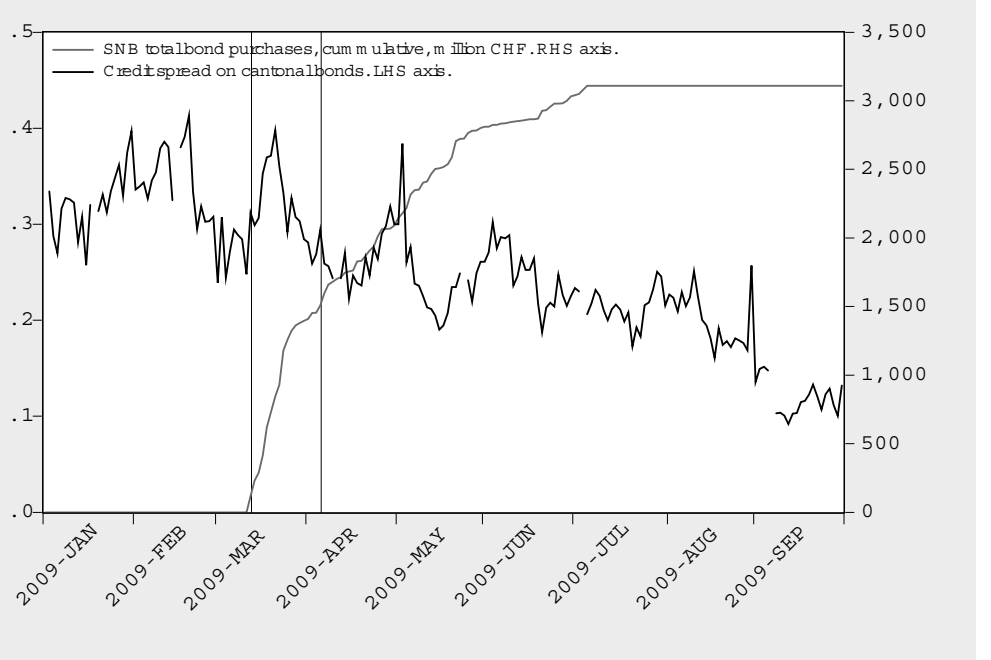

Figure 9: Daily cantonal bond credit index and the SNB total bond purchases, levels

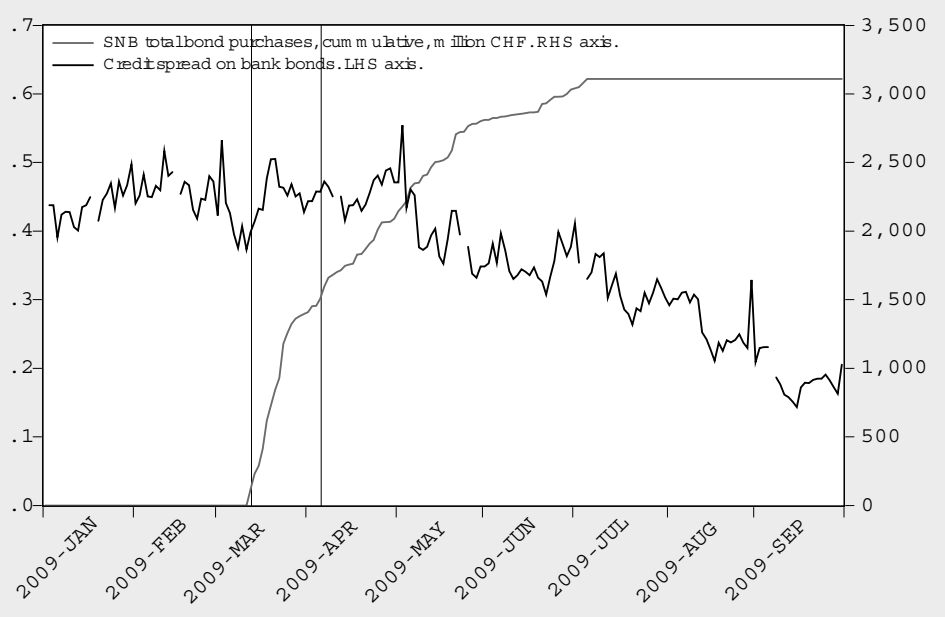

Figure 10: Daily bank bond credit index and the SNB total bond purchases, levels 


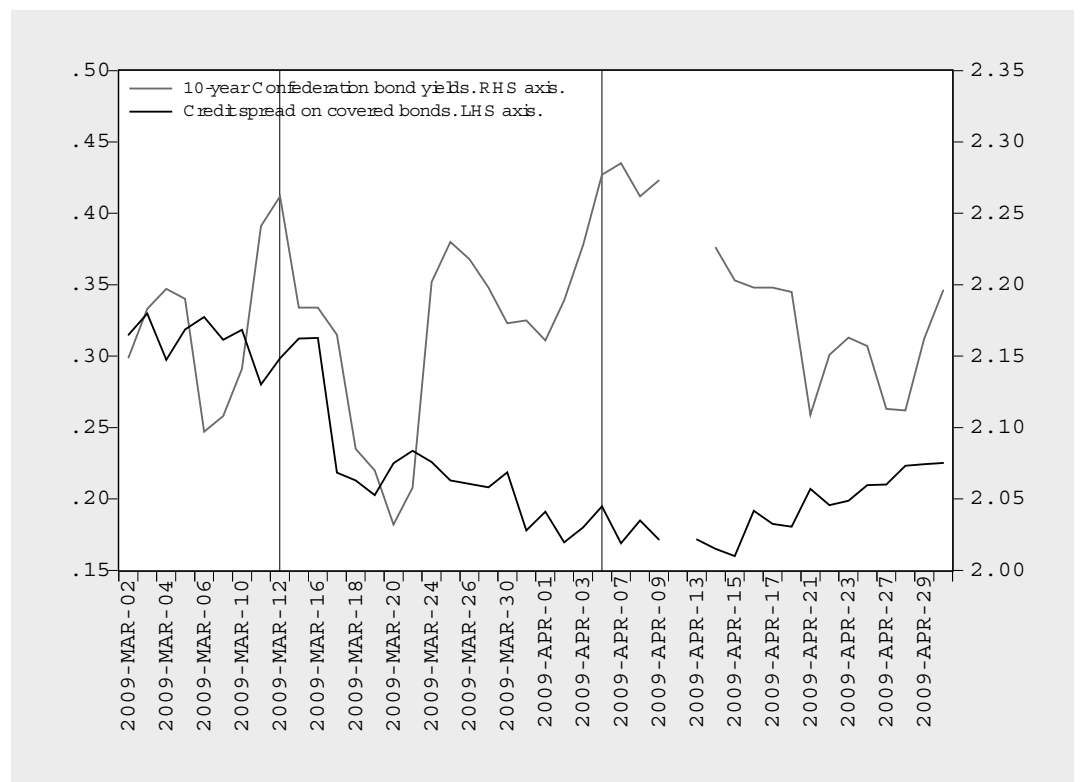

Figure 11: Covered credit spread and Confederation bond yields around the SNB announcement

been responsible for the identified fall in the covered spread, while not affecting the spreads of other bond categories. We were not able to identify any such news or events. It follows that the movement in the covered spread can be interpreted as a delayed discounted portfolio balance effect, materializing after market participants had observed that the SNB was buying covered bonds exclusively in the days after the announcement. In contrast, the purchases of non-bank corporate bonds may never have been substantial enough to produce a detectable market reaction.

Rather than a portfolio balance effect, could the drop in the covered credit spread reflect a lower liquidity risk premium due to an increase in the expected liquidity of covered bonds triggered by the fact that the SNB entered this particular market? Fully excluding this would require assessing the liquidity risk premium rather precisely. Due to data limitations, this is out of the scope of the present paper. However, data on bid-ask spreads, available in the same dataset as that used for computing credit spreads, can provide a hint. We make use of a market liquidity index based on bid-ask spreads, with the underlying assumption being that as market liquidity thins out, bid-ask spreads should widen. While the order-flow literature suggests that bid-ask spreads may capture much more than just liquidity (i.e. Stoll (1978)), a number of empirical studies have found it to work relatively well as a proxy for liquidity (i.e. Fleming (2003)). We hence compute the index as the emissions-weighted average bid-ask spread of the bond category in question. Using this definition, the weighted average bid-ask spread is consistent with the credit spread in terms of types of bonds included in the different categories, the time of day at which the data are collected in the market, and how it relates to the confederation bond market. It turns out that the weighted bid-ask spread is highly positively correlated with the credit spread over the sample period from September 2000 to December 2010, as one would expect if higher bid-ask spreads point to higher liquidity risk premia, which in turn would widen the spread. If bid-ask spreads do contain information about market liquidity, then Figure 12 suggests that the drop in the covered spread between 


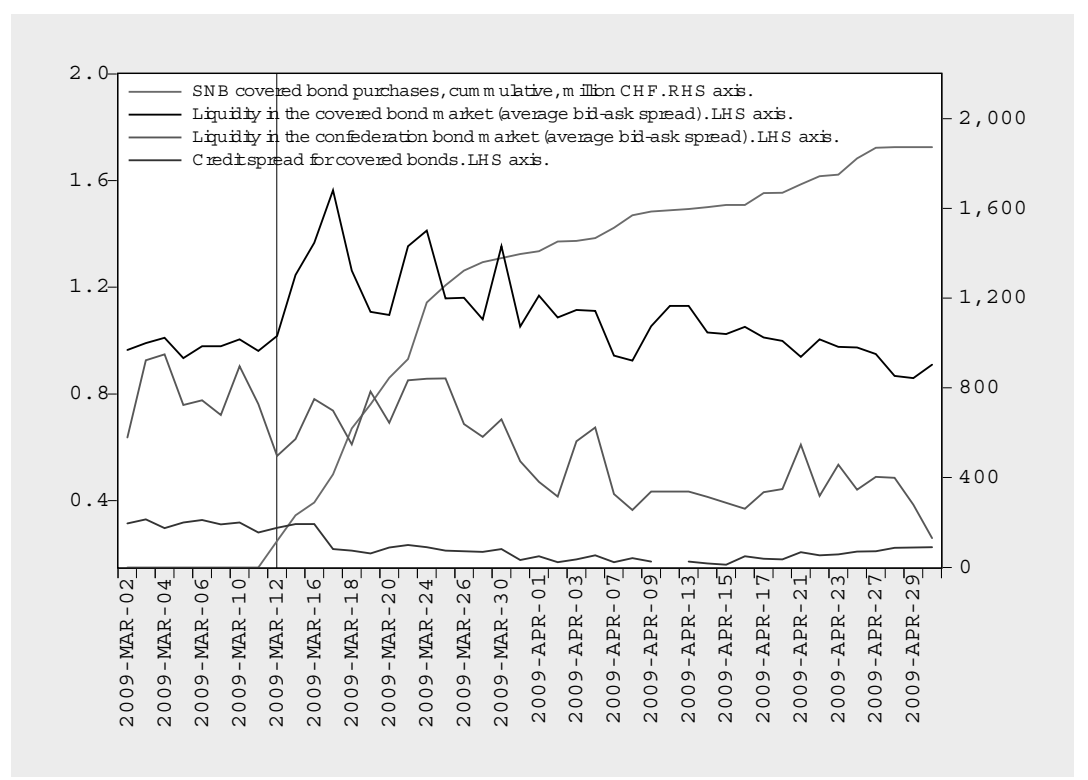

Figure 12: Covered credit spread, market liquidity and SNB bond purchases

the mornings of 16 and 17 March 2009 were not related to lower liquidity premia. Bid-ask spreads in fact increased in the covered bond market in the days following the announcement of the bond purchase program.

In addition to the discounted portfolio balance effect after the announcement and implementation of the program, it is also possible that the subsequent actual purchases could have had additional effects on the spreads at the time of purchase, if these purchases differed from what was expected by market participants. Thus, if market participants had not expected the extent to which covered bonds would be purchased, then the unexpected part of these purchases could have had additional portfolio balance effects. It is not clear from pure visual inspection of the charts that any such effects were present in covered bond spreads at purchase times. In order to control for variation in other factors relevant for bond spreads-notably risk aversion, liquidity and macroeconomic conditions-we conduct a regression analysis in Section 5 below.

\subsection{The unannounced bond sales in $\mathbf{2 0 1 0}$}

The SNB's exit from the bond purchase program could in principle also have had a discounted reserve portfolio balance effect, if market participants had been made aware of the intended bond sales at a specific point in time. This was not the case, however. The exit was never announced, and in fact, awareness of the exit may have happened at different times for different market participants. But it is clear that market participants were not aware that the exit had happened before it had largely taken place. Moreover, judging from the press as well as from anecdotal evidence, there is very little indication that market participants were expecting the exit to happen in 2010. Hence, the bond sales in 2010 could have had a systematic effect on credit spreads at the times of the actual sales, if central bank open market operations have portfolio balance effects and if such effects can materialize without market participants being explicitly aware of a change in market volumes. Figures 13 to 14 show 


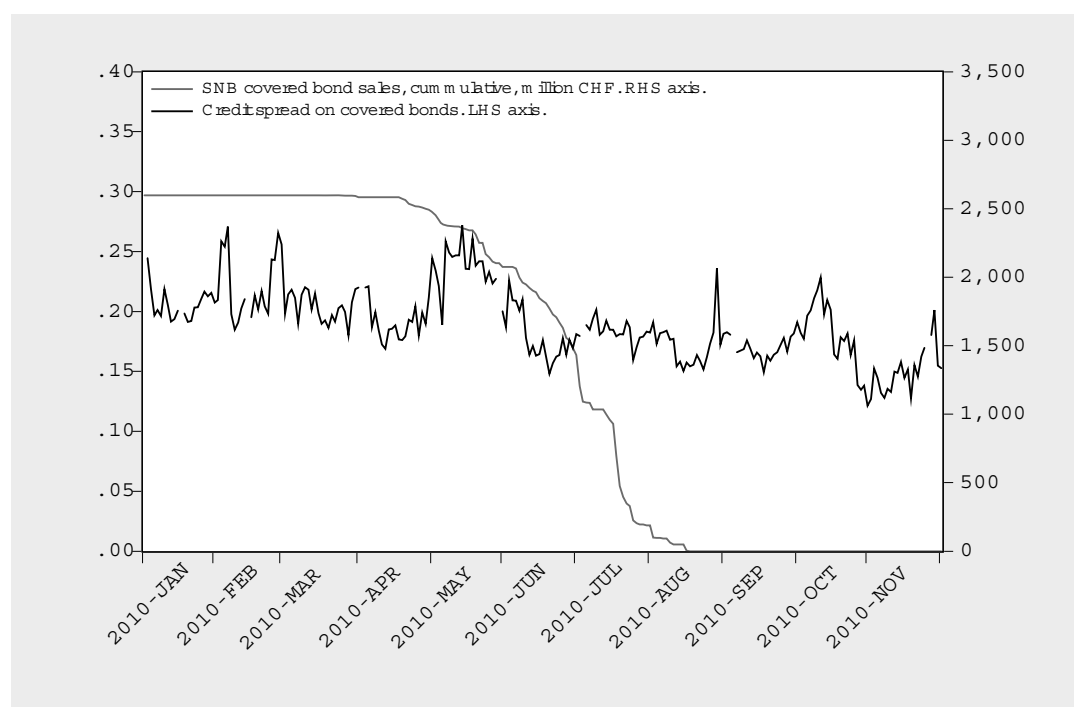

Figure 13: Daily covered credit index and the SNB covered bond sales in 2010, levels

the covered and corporate bond credit spreads and the SNB holdings of the corresponding bonds during the period of the sales in 2010 respectively. The Figures show very little sign of an increase in bond spreads as a result of the sales. There is no clear consistent reaction of the spread around the times of the sales, and spreads tend to generally decline rather than increase over the time period. Of course, it cannot be excluded that this lack of visual evidence of an effect is due to reverse causality (the same holds true for the the effect of the bond purchases above). The SNB's decisions to sell the bonds are likely to have been affected by market conditions, including movements in the actual spreads on the bonds to be sold, with the aim of preventing a market impact. In the regression analysis in Section 5, we attempt to control for such reverse causality, but are not able to derive strong conclusions due to a lack of appropriate instruments.

\subsection{Conclusions from the event analysis}

The event study supports the hypothesis that when the markets had observed the SNB's purchases of covered bonds in the days following the announcement of the program, an expected portfolio balance effect of the SNB's total expected purchases was discounted, leading to a decline in the covered bond spread of about 10 basis points. No such effect was observed in the spread for corporate bonds or any other bond category. Spreads generally declined in the months following the first purchases, as we would expect from a further portfolio balance effect on spreads. In contrast, spreads also slightly declined during the period of the bond sales, whereas a portfolio balance effect of the sales should generate an increase in spreads. It is hence not clear from the data that portfolio balance effects were present beyond the initial discounted effect in the days following the announcement.

While these visual impressions are suggestive, no firm conclusions can be drawn on causality between the SNB bond purchase program and credit spread from the figures alone. ${ }^{4}$ First,

\footnotetext{
${ }^{4}$ This point is made by Stroebel and Taylor (2012) in a general critique of the event analysis approach to
} 


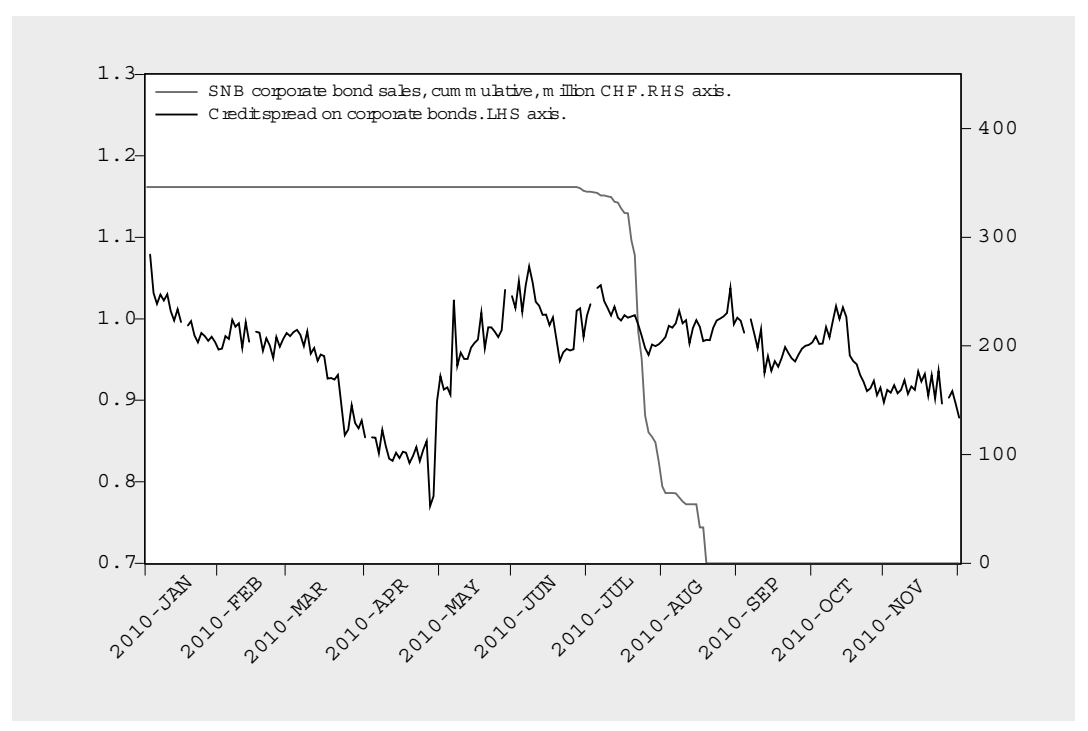

Figure 14: Daily corporate credit index and the SNB corporate bond sales in 2010, levels

we need to investigate whether the decline in the covered spread in the days after the announcement of the program was statistically significant. Moreover, we also need to control for movements in other factors during the period in question. In particular, we need to assess whether the subsequent bond purchases and sales might have had independent effects on credit spreads aside from the announcement, when controlling for the main determinants of credit spreads. We hence turn to econometric analysis of the bond purchase program.

\section{Econometric investigation}

We carry out regressions for the covered and non-bank corporate spread respectively, on dummies for the days within the announcement window and the actual SNB bond purchases and sales. We control for proxies for default risk, risk aversion, liquidity and general economic conditions. The sample period is September 2000 to December 2010. We use daily data, which allows us to carefully assess the effect of the announcement of the program and possible immediate effects of purchases on bond markets. The regressions are estimated in first differences so as to circumvent non-stationarity problems (the credit spread has a unit root, whereas the first difference is stationary). The baseline regression specification is in line with the literature, e.g. Collin-Dufresne et al. (2001) and Avramov et al. (2007). It should be noted that portfolio balance effects of the actual purchases could materialize with a longer delay than what we can allow for in a daily first differences specification. However, it is more difficult to establish causality in levels regressions and regressions using weekly or monthly frequency. We hence only carry out such regressions as a robustness checks. The baseline specification is the following:

assessing the effects of the various asset purchase programs conducted by the Federal Reserve since the onset of the financial crisis. 


$$
\begin{aligned}
\Delta c i_{t}= & \sum_{i=1}^{3} \beta_{\text {covered }_{i}} D_{t-i}^{\text {covered }}+\sum_{i=1}^{3} \beta_{\text {corp }_{i}} D_{t-i}^{\text {corp }}+\sum_{i=0}^{1} \beta_{\text {snb } b_{i}} \Delta S N B b_{t-i}+\beta_{\text {vol }_{\text {vol }}-1} \\
& +\beta_{S P I} \Delta S P I_{t-1}+\beta_{B A} \Delta B i d A s k_{t}+\beta_{T S} \Delta T S_{t}+\beta_{R} \Delta R_{t}^{10 y}+u_{t},
\end{aligned}
$$

where $c i_{t}$ is the relevant credit spread. $D_{t}^{\text {covered }}$ is a dummy taking the value one on the day of the announcement and first purchases of covered bonds, i.e. on the 12 March 2009, and $D_{t}^{\text {corp }}$ is a dummy taking the value one on the day of the first purchases of non-bank corporate bonds. For consistency, both dummies are included with three lags to mirror the event window identified in Section 4 above. The choice of three daily lags of the announcement dummy allows us to test whether the strong drop in the covered bond spread between the second and third business day after the announcement is significant when controlling for other determinants of the spread. We do not include the contemporaneous announcement dummy, because the press release and first purchases were made in the afternoon of the 12th of March, whereas the data used for the calculation of the credit spread is collected during the morning. $\triangle S N B b_{t}$ captures the actual monthly purchases (+) and sales (-) of covered and/or corporate bonds by the SNB in the period between March 2009 and August 2010. We include the contemporaneous purchases and sales as well as a lag. The contemporaneous value would capture immediate effects of bond purchases or sales carried out in the morning, before the credit spread is recording. The lag is included in order to allow for all purchases or sales that have taken place after the time of the recording of the credit spread to have an effect on the credit spread the morning after. The purchases and sales are measured in percent of the corresponding bond category's emission volumes.

The control variables are the following. $v o l_{t}$ is the conditional stock price volatility estimated during the sample period, included to control for a link between credit spreads and high volatility periods (risk aversion). ${ }^{5} S P I_{t}$ is a measure of expected loss due to default, which we - following the previous literature - proxy by the log of the level of the main Swiss stock price index, the SPI. Note that the SPI also captures the overall performance of the economy. Volatility and the SPI are lagged one day to account for the fact that the data for these variables are collected at market close while the data on credit spreads are collected during the morning. All other daily variables are collected during the morning, and hence included as contemporary variables only. In order to control for changes in market liquidity around the announcement and purchase times, we include the average emission-volume-weighted bid-ask spread of the bond category in question, less the average emission-volume-weighted bid-ask spread for confederation bonds. The bid-ask spread is computed as the difference between the black and green lines in Figure 12, which are explained in Section 4.1.

Macroeconomic developments are further controlled for by including the long term interest rate level, i.e. the 10-year Confederation bond yield $R_{t}^{10 y}$. Its empirical prior is negative (see Collin-Dufresne et al. (2001)). A higher level of interest rates reflects strong business cycle developments, which is good for firm profitability. Finally, we follow Fama and French (1989) and include the term spread, $T S_{t}$, defined as the difference between the 10-year Confederation

\footnotetext{
${ }^{5}$ We also tried using the VIX, and the expected stock price volatility based on the SPI. Results and conclusions were unchanged.
} 
bond yield and the three-month CHF libor. A higher term spread could be taken to signal higher uncertainty about future economic outcomes, suggesting a positive relation with credit spreads.

We do not include intercepts in the regressions for which we report the results, given that first differences are used. Whether or not an intercept is included makes not difference to the results. Moreover, intercepts are never significantly different from zero.

\subsection{Regression results}

Table 1 presents the results for the baseline regression using daily data for covered and nonbank corporate spreads in column one and two. Most control variables have the correct signs, and the term spread and the long-term bond yield are significant.

Confirming the visual impressions of Section 4, the third lag of the announcement and purchases dummy for covered bonds is significantly negative in the covered bond spread regression, suggesting that the spread declined by about 10 basis points on that day without any of the control variables included in the regression being able to account for that. The decline is significantly different from zero at the $1 \%$ level. It is hence plausible that it is the result of the markets' evolving perception regarding the SNB intentions of purchasing covered bonds. 
Table 1: Baseline regression results

\begin{tabular}{|c|c|c|}
\hline & $\frac{\text { Covered Bonds }}{(1)}$ & $\frac{\text { Corporate Bonds }}{(2)}$ \\
\hline$\overline{D_{t-1}^{s n b c o v}}$ & $\begin{array}{l}.001 \\
(.002)\end{array}$ & $\begin{array}{l}.002 \\
(.004)\end{array}$ \\
\hline$D_{t-2}^{s n b c o v}$ & $\begin{array}{l}.000 \\
(.002)\end{array}$ & $\begin{array}{c}-.006 \\
(.002)^{* * *}\end{array}$ \\
\hline$D_{t-3}^{s n b c o v}$ & $\begin{array}{c}-.098 \\
(.002)^{* * *}\end{array}$ & $\begin{array}{c}.017 \\
(.002)^{* * *}\end{array}$ \\
\hline$D_{t-1}^{s n b c o r p}$ & $\begin{array}{c}-.027 \\
(.001)^{* * *}\end{array}$ & $\begin{array}{c}-.030 \\
(.009)^{* * *}\end{array}$ \\
\hline$D_{t-2}^{s n b c o r p}$ & $\begin{array}{c}.012 \\
(.001)^{* * *}\end{array}$ & $\begin{array}{l}.009 \\
(.011)\end{array}$ \\
\hline$D_{t-3}^{s n b c o r p}$ & $\begin{array}{c}-.012 \\
(.001)^{* * *}\end{array}$ & $\begin{array}{c}.018 \\
(.002)^{* * *}\end{array}$ \\
\hline$\Delta S N B b_{t}^{c o v}$ & $\begin{array}{l}1.042 \\
(.694)\end{array}$ & \\
\hline$\Delta S N B b_{t-1}^{c o v}$ & $\begin{array}{r}-.654 \\
(.780)\end{array}$ & \\
\hline$\Delta S N B b_{t}^{c o r p}$ & & $\begin{array}{c}-1.418 \\
(4.870)\end{array}$ \\
\hline$\Delta S N B b_{t-1}^{c o r p}$ & & $\begin{array}{l}1.549 \\
(4.616)\end{array}$ \\
\hline$\Delta v o l_{t-1} \cdot 100$ & $\begin{array}{r}-.150 \\
(.170)\end{array}$ & $\begin{array}{l}-.106 \\
(.261)\end{array}$ \\
\hline$\Delta \log S P I_{t-1}$ & $\begin{array}{r}-.053 \\
(.040)\end{array}$ & $\begin{array}{r}-.032 \\
(.069)\end{array}$ \\
\hline$\Delta B i d A s k_{t}$ & $\begin{array}{l}.002 \\
(.003)\end{array}$ & $\begin{array}{l}.004 \\
(.005)\end{array}$ \\
\hline$\Delta T S_{t}$ & $\begin{array}{c}.093 \\
(.032)^{* * *}\end{array}$ & $\begin{array}{c}.146 \\
(.054)^{* * *}\end{array}$ \\
\hline$\Delta R_{t}^{10 y}$ & $\begin{array}{c}-.194 \\
(.032)^{* * *}\end{array}$ & $\begin{array}{c}-.380 \\
(.058)^{* * *}\end{array}$ \\
\hline $\begin{array}{l}\text { Obs. } \\
R^{2}\end{array}$ & $\begin{array}{r}2307 \\
.057\end{array}$ & $\begin{array}{c}2302 \\
.079\end{array}$ \\
\hline
\end{tabular}

Notes: The sample period is September $1^{\text {st }}, 2000$, until December $31^{\text {th }}, 2010$. The numbers in parentheses are heteroskedasticity- and autocorrelation-consistent (Newey-West) standard errors.

${ }^{*} p<0.10,{ }^{* *} p<0.05,{ }^{* * *} p<0.01$.

The results also confirm that the announcement did not affect corporate bonds to the same degree. The second lag after announcement is significantly negative, while the third lag is positive. None of the estimated parameters for the lags are of an economically relevant size. The same lack of economic relevance holds true for the dummy for the beginning of the corporate bond purchases on the 6th April 2009.

Turning to the parameter estimates for the outright bond purchases and sales of the SNB, 
these come with the expected negative sign, but they are insignificant in both regressions. The data thus does not support the hypothesis that there were additional immediate portfolio balance effects associated with the outright purchases and sales. Given that market participants had very different information sets about the purchases and sales, it is possible that the effect of the two on markets would be different. Using a dummy taking the value one from January 2010 onwards, the specification in Table 2 allows the effects of the purchases and the effects of the sales in 2010 to differ. Again, neither the purchases nor the sales have significant effects on credit spreads.

Table 2: Baseline with an interaction dummy for bond sales

\begin{tabular}{|c|c|c|}
\hline & $\frac{\text { Covered Bonds }}{(1)}$ & $\frac{\text { Corporate Bonds }}{(2)}$ \\
\hline$\overline{D_{t-1}^{s n b c o v}}$ & $\begin{array}{l}.014 \\
(.026)\end{array}$ & $\begin{array}{l}.002 \\
(.004)\end{array}$ \\
\hline$D_{t-2}^{s n b c o v}$ & $\begin{array}{r}-.057 \\
(.150)\end{array}$ & $\begin{array}{l}-.007 \\
(.002)^{* * *}\end{array}$ \\
\hline$D_{t-3}^{s n b c o v}$ & $\begin{array}{r}-.001 \\
(.234)\end{array}$ & $\begin{array}{c}.016 \\
(.002)^{* * *}\end{array}$ \\
\hline$D_{t-1}^{\text {snbcorp }}$ & $\begin{array}{l}.017 \\
(.107)\end{array}$ & $\begin{array}{l}-.048 \\
(.022)^{* *}\end{array}$ \\
\hline$D_{t-2}^{\text {snbcorp }}$ & $\begin{array}{l}.033 \\
(.049)\end{array}$ & $\begin{array}{l}.073 \\
(.091)\end{array}$ \\
\hline$D_{t-3}^{\text {snbcorp }}$ & $\begin{array}{l}-.055 \\
(.110)\end{array}$ & $\begin{array}{l}.025 \\
(.011)^{* *}\end{array}$ \\
\hline$\Delta S N B b_{t}^{c o v}$ & $\begin{array}{l}-45.120 \\
(113.523)\end{array}$ & \\
\hline$\Delta S N B b_{t-1}^{c o v}$ & $\begin{array}{c}40.104 \\
(102.892)\end{array}$ & \\
\hline$\Delta S N B b_{t}^{\text {corp }}$ & & $\begin{array}{l}30.933 \\
(42.239)\end{array}$ \\
\hline$\Delta S N B b_{t-1}^{c o r p}$ & & $\begin{array}{l}-26.930 \\
(40.111)\end{array}$ \\
\hline Obs. & 2129 & 2124 \\
\hline$R^{2}$ & .055 & .075 \\
\hline
\end{tabular}

Notes: The sample period is September $1^{\text {st }}, 2000$, until December $31^{\text {th }}, 2010$. The numbers in parentheses are heteroskedasticity- and autocorrelation-consistent (Newey-West) standard errors.

${ }^{*} p<0.10,{ }^{* *} p<0.05,{ }^{* * *} p<0.01$.

The lack of an effect of the outright bond market interventions could reflect the efficient markets hypothesis that the effect of the purchases was discounted in the price of covered bonds as soon as the markets has realized that the SNB would be buying covered bonds. This interpretation implies that markets knew what the aggregate portfolio balance effect of the purchases would be, and expected correctly when they would be sold off again. This seems unlikely. Alternatively, the lack of an effect of the interventions would also be consistent with the view that markets discounted an expected effect of the interventions, but that no such 
effect exists if markets are unaware of the central bank's actions.

In conclusion, the data supports the hypothesis that there was an announcement effect of the first covered bond purchases on the spreads of covered bonds. However, there is no evidence in the data of an economically relevant effect of the bond purchase program on nonbank corporate bonds.

\subsection{Robustness}

Tables 3 to 7 display the results of a series of robustness tests. First, as already discussed in Section 4, it is likely that the SNB adjusted its purchases and sales according to the market conditions of the purchased bonds. For example, it is possible that covered bonds were purchased in larger quantities on days where prices of these were going down and yields up, as it was the intention of the SNB to reduce the yield spreads. Similarly, it is likely that more bonds were sold on days when the prices of the bonds were increasing and yields falling, during the sales period in 2010. This suggests a source of endogneity of the SNB's bond market interventions which would tend to bias the parameter estimates of the regressions downward. There are two ways of addressing this type of endogeneity in the literature (see for example Manganelli (2012) and references therein). One way is to investigate intra-day high-frequency data. We do not have intra-day data on credit spreads. The second option is to use instruments. We are not aware of any good instrumental variable for SNB bond market interventions. We instead tried to carry out a TSLS regression using lags of the explanatory variables as instruments. As could be expected, standard errors increase strongly, leading to a decline in significance. The conclusions from using instruments are largely the same as those from standard regressions, and we hence do not report the results here. ${ }^{6}$ In lack of appropriate instruments, however, it is not possible to make any firm conclusions on the lack of an effect.

Second, Table 3 shows that a longer average maturity of outstanding total bonds is found to significantly reduce the covered credit spread. However, the inclusion of average maturity does not affect the conclusions from the baseline regressions. It should be added that no redemptions or new issues of covered bonds took place during the week after the announcements of the bond purchase program, and hence, that there was no exceptional variation in the average maturity in those days.

Third, in the months and year after the announcement of the SNB bond purchase program, corporate spreads generally declined in western countries. This was a period of increasing calm in global financial markets. Could the decline in the covered spread following the announcement of the bond purchase program have reflected a more general decline in international corporate spreads? Table 4 shows that controlling for movements in different types of US and European corporate spreads do not change the findings. The foreign spreads used here are not even significant in explaining daily changes in Swiss covered and corporate spreads.

Fourth, Table 5 shows the regression results when controlling for the market liquidity of

\footnotetext{
${ }^{6}$ The results are available upon request.
} 
Table 3: Controlling for the average maturity of the bonds within the given category

\begin{tabular}{|c|c|c|}
\hline & \multirow{2}{*}{$\frac{\text { Covered Bonds }}{(1)}$} & \multirow{2}{*}{$\frac{\text { Corporate Bonds }}{(2)}$} \\
\hline & & \\
\hline$\overline{D_{t-1}^{s n b c o v}}$ & $\begin{array}{l}.001 \\
(.002)\end{array}$ & $\begin{array}{l}.002 \\
(.004)\end{array}$ \\
\hline$D_{t-2}^{s n b c o v}$ & $\begin{array}{l}.000 \\
(.002)\end{array}$ & $\begin{array}{l}-.006 \\
(.002)^{* * *}\end{array}$ \\
\hline$D_{t-3}^{s n b c o v}$ & $\begin{array}{c}-.098 \\
(.002)^{* * *}\end{array}$ & $\begin{array}{c}.017 \\
(.002)^{* * *}\end{array}$ \\
\hline$D_{t-1}^{s n b c o r p}$ & $\begin{array}{c}-.028 \\
(.001)^{* * *}\end{array}$ & $\begin{array}{c}-.030 \\
(.009)^{* * *}\end{array}$ \\
\hline$D_{t-2}^{s n b c o r p}$ & $\begin{array}{c}.011 \\
(.001)^{* * *}\end{array}$ & $\begin{array}{l}.009 \\
(.011)\end{array}$ \\
\hline$D_{t-3}^{\text {snbcorp }}$ & $\begin{array}{l}-.012 \\
(.001)^{* * *}\end{array}$ & $\begin{array}{c}.018 \\
(.002)^{* * *}\end{array}$ \\
\hline$\Delta S N B b_{t}^{c o v}$ & $\begin{array}{l}1.016 \\
(.694)\end{array}$ & \\
\hline$\Delta S N B b_{t-1}^{c o v}$ & $\begin{array}{l}-.656 \\
(.777)\end{array}$ & \\
\hline$\Delta S N B b_{t}^{\operatorname{corp}}$ & & $\begin{array}{c}-1.418 \\
(4.867)\end{array}$ \\
\hline$\Delta S N B b_{t-1}^{c o r p}$ & & $\begin{array}{l}1.534 \\
(4.621)\end{array}$ \\
\hline$\Delta v l_{t-1} \cdot 100$ & $\begin{array}{r}-.149 \\
(.170)\end{array}$ & $\begin{array}{r}-.106 \\
(.261)\end{array}$ \\
\hline$\Delta \log S P I_{t-1}$ & $\begin{array}{r}-.051 \\
(.040)\end{array}$ & $\begin{array}{r}-.032 \\
(.069)\end{array}$ \\
\hline$\Delta B i d A s k_{t}$ & $\begin{array}{l}.002 \\
(.003)\end{array}$ & $\begin{array}{l}.004 \\
(.005)\end{array}$ \\
\hline$\Delta T S_{t}$ & $\begin{array}{c}.091 \\
(.033)^{* * * *}\end{array}$ & $\begin{array}{c}.146 \\
(.054)^{* * *}\end{array}$ \\
\hline$\Delta R_{t}^{10 y}$ & $\begin{array}{l}-.192 \\
(.033)^{* * *}\end{array}$ & $\begin{array}{c}-.380 \\
(.058)^{* * *}\end{array}$ \\
\hline$\Delta \log M a t_{t}^{p f}$ & $\begin{array}{c}-.776 \\
(.289)^{* * *}\end{array}$ & $\begin{array}{l}.084 \\
(.412)\end{array}$ \\
\hline $\begin{array}{l}\text { Obs. } \\
R^{2}\end{array}$ & $\begin{array}{r}2307 \\
.059\end{array}$ & $\begin{array}{c}2302 \\
.079\end{array}$ \\
\hline
\end{tabular}

Notes: The sample period is September $1^{\text {st }}, 2000$, until December $31^{\text {th }}, 2010$. The numbers in parentheses are heteroskedasticity and autocorrelation consistent (Newey-West) standard errors.

${ }^{*} p<0.10,{ }^{* *} p<0.05,{ }^{* * *} p<0.01$. 
Table 4: Controlling for movements in foreign corporate spreads

\begin{tabular}{|c|c|c|}
\hline & $\frac{\text { Covered Bonds }}{(1)}$ & $\frac{\text { Corporate Bonds }}{(2)}$ \\
\hline$\overline{D_{t-1}^{s n b c o v}}$ & $\begin{array}{l}.003 \\
(.003)\end{array}$ & $\begin{array}{l}.003 \\
(.004)\end{array}$ \\
\hline$D_{t-2}^{s n b c o v}$ & $\begin{array}{l}.011 \\
(.009)\end{array}$ & $\begin{array}{l}.000 \\
(.008)\end{array}$ \\
\hline$D_{t-3}^{s n b c o v}$ & $\begin{array}{c}-.095 \\
(.004)^{* * *}\end{array}$ & $\begin{array}{c}.019 \\
(.004)^{* * *}\end{array}$ \\
\hline$D_{t-1}^{s n b c o r p}$ & $\begin{array}{c}-.028 \\
(.001)^{* * *}\end{array}$ & $\begin{array}{l}-.030 \\
(.008)^{* * *}\end{array}$ \\
\hline$D_{t-2}^{s n b c o r p}$ & $\begin{array}{c}.011 \\
(.001)^{* * *}\end{array}$ & $\begin{array}{l}.011 \\
(.011)\end{array}$ \\
\hline$D_{t-3}^{s n b c o r p}$ & $\begin{array}{c}-.013 \\
(.002)^{* * *}\end{array}$ & $\begin{array}{c}.017 \\
(.002)^{* * *}\end{array}$ \\
\hline$\Delta S N B b_{t}^{c o v}$ & $\begin{array}{l}1.291 \\
(.741)^{*}\end{array}$ & \\
\hline$\Delta S N B b_{t-1}^{c o v}$ & $\begin{array}{r}-.708 \\
(.796)\end{array}$ & \\
\hline$\Delta S N B b_{t}^{\operatorname{corp}}$ & & $\begin{array}{c}-1.029 \\
(4.722)\end{array}$ \\
\hline$\Delta S N B b_{t-1}^{c o r p}$ & & $\begin{array}{l}1.199 \\
(4.715)\end{array}$ \\
\hline$\Delta v l_{t-1} \cdot 100$ & $\begin{array}{r}-.156 \\
(.181)\end{array}$ & $\begin{array}{l}-.115 \\
(.256)\end{array}$ \\
\hline$\Delta \log S P I_{t-1}$ & $\begin{array}{r}-.044 \\
(.040)\end{array}$ & $\begin{array}{l}-.009 \\
(.075)\end{array}$ \\
\hline$\Delta B i d A s k_{t}$ & $\begin{array}{l}.003 \\
(.003)\end{array}$ & $\begin{array}{l}.004 \\
(.005)\end{array}$ \\
\hline$\Delta T S_{t}$ & $\begin{array}{c}.093 \\
(.032)^{* * *}\end{array}$ & $\begin{array}{c}.144 \\
(.055)^{* * *}\end{array}$ \\
\hline$\Delta R_{t}^{10 y}$ & $\begin{array}{c}-.193 \\
(.032)^{* * *}\end{array}$ & $\begin{array}{c}-.375 \\
(.058)^{* * *}\end{array}$ \\
\hline$\Delta \operatorname{Corp} H L_{t}^{u s}$ & $\begin{array}{r}-.022 \\
(.019)\end{array}$ & $\begin{array}{r}-.012 \\
(.017)\end{array}$ \\
\hline$\Delta C \operatorname{cop} H L_{t}^{e u}$ & $\begin{array}{l}.022 \\
(.015)\end{array}$ & $\begin{array}{l}.043 \\
(.030)\end{array}$ \\
\hline $\begin{array}{l}\text { Obs. } \\
R^{2}\end{array}$ & $\begin{array}{c}2307 \\
.061\end{array}$ & $\begin{array}{r}2302 \\
.082\end{array}$ \\
\hline
\end{tabular}

Notes: The sample period is September $1^{\text {st }}, 2000$, until December $318^{\text {th }}, 2010$. The numbers in parentheses are heteroskedasticity and autocorrelation consistent (Newey-West) standard errors.

${ }^{*} p<0.10,{ }^{* *} p<0.05,{ }^{* * *} p<0.01$. 
the purchased bonds independently of the market liquidity of confederation bonds. The results confirm the conclusions derived from Figure 12. The average bid-ask spread as a proxy for market liquidity is not significant and its inclusion does not change the finding that the covered credit spread fell significantly in the days following the announcement.

Fifth, Table 6 uses a different proxy for risk aversion, namely the spread between the 3 -month Libor and the 3-month term overnight interest swap rate. The change of control variable is inconsequential for the significance of the relevant parameter estimates.

Further, as already commented on in Section 4, Figure 7 suggest that some periods are more volatile than others, i.e. that the first differences of credit spreads has time varying variation. We allow for time varying variation by estimating a Garch $(1,1)$ specification using maximum likelihood techniques. The GARCH specification becomes:

$$
\begin{gathered}
\Delta c i_{t}=\alpha+\beta_{\sigma} \sigma_{t}^{2}+\beta_{S P I} \Delta S P I_{t-1}+\beta_{s n b} \Delta S N B b_{t}+\beta_{d c o v} \Delta D_{t-1}^{\text {snbcov }} \\
+\beta_{d c o r p} \Delta D_{t-1}^{s n b c o r p}+\beta_{T S} \Delta T S_{t}+\beta_{R} \Delta R_{t}^{10 y}+\beta_{B A} \Delta B i d A s k_{t}+u_{t}, \\
\sigma_{t}^{2}=\omega+\alpha u_{t-1}^{2}+\beta \sigma_{t-1}^{2}, \\
u_{t} \mid \mathcal{F}_{t-1} \sim \mathcal{N}\left(0, \sigma_{t}^{2}\right),
\end{gathered}
$$

where $\mathcal{F}_{t-1}$ is the information set in period t-1. Results for the estimation of this specification, given in Table 7 , confirm the results from the baseline specification.

Finally, the lack of significance of the actual bond purchases and sales in the credit spread regressions could be taken to reflect the daily frequency of the data used and/or the use of first differences. We find that this is not the case. In regressions in levels, with and without a lagged dependent, the outright purchases and sales remain largely insignificant (not shown). ${ }^{7}$

\footnotetext{
${ }^{7}$ There is an exception, in that the outright corporate bond purchases turn significant in some specifications. But when this is the case, the contemporaneous and lagged effects cancel out. Moreover, the finding is not robust. The results from the levels regressions show clear signs of misspecification, with high autocorrelation and very instable parameter estimates. Results from the levels regressions are available from the authors.
} 
Table 5: Including liquidity measures for Confederation, Covered and Corporate bonds separately

\begin{tabular}{|c|c|c|}
\hline & Covered Bonds & Corporate Bonds \\
\hline & $(1)$ & $(2)$ \\
\hline$\overline{D_{t-1}^{s n b c o v}}$ & $\begin{array}{l}.004 \\
(.003)\end{array}$ & $\begin{array}{l}.004 \\
(.004)\end{array}$ \\
\hline$D_{t-2}^{s n b c o v}$ & $\begin{array}{l}.002 \\
(.002)\end{array}$ & $\begin{array}{l}-.007 \\
(.002)^{* * *}\end{array}$ \\
\hline$D_{t-3}^{s n b c o v}$ & $\begin{array}{c}-.097 \\
(.002)^{* * *}\end{array}$ & $\begin{array}{c}.019 \\
(.003)^{* * *}\end{array}$ \\
\hline$D_{t-1}^{s n b c o r p}$ & $\begin{array}{c}-.028 \\
(.002)^{* * *}\end{array}$ & $\begin{array}{c}-.031 \\
(.009)^{* * *}\end{array}$ \\
\hline$D_{t-2}^{s n b c o r p}$ & $\begin{array}{c}.012 \\
(.001)^{* * *}\end{array}$ & $\begin{array}{l}.009 \\
(.011)\end{array}$ \\
\hline$D_{t-3}^{s n b c o r p}$ & $\begin{array}{c}-.011 \\
(.002)^{* * *}\end{array}$ & $\begin{array}{c}.019 \\
(.002)^{* * *}\end{array}$ \\
\hline$\Delta S N B b_{t}^{c o v}$ & $\begin{array}{l}.994 \\
(.698)\end{array}$ & \\
\hline$\Delta S N B b_{t-1}^{c o v}$ & $\begin{array}{r}-.703 \\
(.780)\end{array}$ & \\
\hline$\Delta S N B b_{t}^{\operatorname{corp}}$ & & $\begin{array}{c}-1.544 \\
(4.913)\end{array}$ \\
\hline$\Delta S N B b_{t-1}^{c o r p}$ & & $\begin{array}{l}1.734 \\
(4.649)\end{array}$ \\
\hline$\Delta v l_{t-1} \cdot 100$ & $\begin{array}{r}-.156 \\
(.171)\end{array}$ & $\begin{array}{r}-.112 \\
(.262)\end{array}$ \\
\hline$\Delta \log S P I_{t-1}$ & $\begin{array}{r}-.055 \\
(.040)\end{array}$ & $\begin{array}{c}-.039 \\
(.070)\end{array}$ \\
\hline$\Delta B i d A s k_{t}$ & $\begin{array}{r}-.005 \\
(.006)\end{array}$ & $\begin{array}{l}.020 \\
(.019)\end{array}$ \\
\hline$\Delta T S_{t}$ & $\begin{array}{l}.087 \\
(.037)^{* *}\end{array}$ & $\begin{array}{c}.157 \\
(.055)^{* * *}\end{array}$ \\
\hline$\Delta R_{t}^{10 y}$ & $\begin{array}{c}-.175 \\
(.037)^{* * *}\end{array}$ & $\begin{array}{c}-.382 \\
(.059)^{* * *}\end{array}$ \\
\hline$\Delta B i d A s k_{t}^{c o v}$ & $\begin{array}{r}-.005 \\
(.008)\end{array}$ & $\begin{array}{r}-.008 \\
(.008)\end{array}$ \\
\hline$\Delta B i d A s k_{t}^{c o n f}$ & $\begin{array}{r}-.005 \\
(.008)\end{array}$ & $\begin{array}{l}.016 \\
(.018)\end{array}$ \\
\hline Obs. & 2179 & 2179 \\
\hline$R^{2}$ & .051 & .078 \\
\hline
\end{tabular}

Notes: The sample period is September $1^{\text {st }}, 2000$, until December $31^{\text {th }}, 2010$. The numbers in parentheses are heteroskedasticity and autocorrelation consistent (Newey-West) standard errors.

${ }^{*} p<0.10,{ }^{* *} p<0.05,{ }^{* * *} p<0.01$. 
Table 6: Controlling for LibTois

\begin{tabular}{|c|c|c|}
\hline & Covered Bonds & Corporate Bonds \\
\hline & $(1)$ & $(2)$ \\
\hline$\overline{D_{t-1}^{s n b c o v}}$ & $\begin{array}{l}.003 \\
(.002)\end{array}$ & $\begin{array}{l}.002 \\
(.003)\end{array}$ \\
\hline$D_{t-2}^{\text {snbcov }}$ & $\begin{array}{l}.003 \\
(.002)\end{array}$ & $\begin{array}{c}-.004 \\
(.002)^{* *}\end{array}$ \\
\hline$D_{t-3}^{s n b c o v}$ & $\begin{array}{l}-.097 \\
(.002)^{* * *}\end{array}$ & $\begin{array}{c}.017 \\
(.002)^{* * *}\end{array}$ \\
\hline$D_{t-1}^{s n b c o r p}$ & $\begin{array}{l}-.027 \\
(.001)^{* * *}\end{array}$ & $\begin{array}{c}-.027 \\
(.010)^{* * *}\end{array}$ \\
\hline$D_{t-2}^{s n b c o r p}$ & $\begin{array}{c}.014 \\
(.001)^{* * *}\end{array}$ & $\begin{array}{l}.015 \\
(.012)\end{array}$ \\
\hline$D_{t-3}^{s n b c o r p}$ & $\begin{array}{l}-.011 \\
(.001)^{* * *}\end{array}$ & $\begin{array}{c}.019 \\
(.002)^{* * *}\end{array}$ \\
\hline$\Delta S N B b_{t}^{c o v}$ & $\begin{array}{l}.857 \\
(.723)\end{array}$ & \\
\hline$\Delta S N B b_{t-1}^{c o v}$ & $\begin{array}{r}-.625 \\
(.783)\end{array}$ & \\
\hline$\Delta S N B b_{t}^{c o r p}$ & & $\begin{array}{l}-.707 \\
(4.910)\end{array}$ \\
\hline$\Delta S N B b_{t-1}^{c o r p}$ & & $\begin{array}{l}-.244 \\
(4.780)\end{array}$ \\
\hline$\Delta$ LibTois $_{t-1} \cdot 100$ & $\begin{array}{l}.039 \\
(.027)\end{array}$ & $\begin{array}{l}.033 \\
(.037)\end{array}$ \\
\hline$\Delta \log S P I_{t-1}$ & $\begin{array}{r}-.053 \\
(.041)\end{array}$ & $\begin{array}{l}-.015 \\
(.071)\end{array}$ \\
\hline$\Delta B i d A s k_{t}$ & $\begin{array}{l}.003 \\
(.003)\end{array}$ & $\begin{array}{l}.004 \\
(.006)\end{array}$ \\
\hline$\Delta T S_{t}$ & $\begin{array}{c}.078 \\
(.031)^{* *}\end{array}$ & $\begin{array}{c}.134 \\
(.053)^{* *}\end{array}$ \\
\hline$\Delta R_{t}^{10 y}$ & $\begin{array}{c}-.176 \\
(.031)^{* * *}\end{array}$ & $\begin{array}{c}-.371 \\
(.056)^{* * *}\end{array}$ \\
\hline Obs. & 2167 & 2162 \\
\hline$R^{2}$ & .06 & .082 \\
\hline
\end{tabular}

Notes: The sample period is September $1^{\text {st }}, 2000$, until December $31^{\text {th }}, 2010$. The numbers in parentheses are heteroskedasticity and autocorrelation consistent (Newey-West) standard errors.

${ }^{*} p<0.10,{ }^{* *} p<0.05,{ }^{* * *} p<0.01$. 
Table 7: GARCH estimates: conditional volatility (OIM)

\begin{tabular}{|c|c|c|}
\hline & Covered Bonds & Corporate Bonds \\
\hline & $(1)$ & $(2)$ \\
\hline$\overline{D_{t-1}^{s n b c o v}}$ & $\begin{array}{l}.006 \\
(.014)\end{array}$ & $\begin{array}{l}.008 \\
(.031)\end{array}$ \\
\hline$D_{t-2}^{s n b c o v}$ & $\begin{array}{l}.002 \\
(.014)\end{array}$ & $\begin{array}{l}-.004 \\
(.015)\end{array}$ \\
\hline$D_{t-3}^{s n b c o v}$ & $\begin{array}{c}-.098 \\
(.013)^{* * *}\end{array}$ & $\begin{array}{l}.019 \\
(.014)\end{array}$ \\
\hline$D_{t-1}^{s n b c o r p}$ & $\begin{array}{c}-.027 \\
(.011)^{* *}\end{array}$ & $\begin{array}{c}-.034 \\
(.017)^{* *}\end{array}$ \\
\hline$D_{t-2}^{s n b c o r p}$ & $\begin{array}{l}.013 \\
(.010)\end{array}$ & $\begin{array}{l}.006 \\
(.015)\end{array}$ \\
\hline$D_{t-3}^{s n b c o r p}$ & $\begin{array}{r}-.011 \\
(.010)\end{array}$ & $\begin{array}{l}.018 \\
(.011)\end{array}$ \\
\hline$\Delta S N B b_{t}^{c o v}$ & $\begin{array}{l}1.170 \\
(.824)\end{array}$ & \\
\hline$\Delta S N B b_{t-1}^{c o v}$ & $\begin{array}{c}-1.256 \\
(.841)\end{array}$ & \\
\hline$\Delta S N B b_{t}^{\operatorname{corp}}$ & & $\begin{array}{c}-1.396 \\
(3.746)\end{array}$ \\
\hline$\Delta S N B b_{t-1}^{c o r p}$ & & $\begin{array}{l}3.515 \\
(3.469)\end{array}$ \\
\hline$\Delta \log S P I_{t-1}$ & $\begin{array}{l}-.019 \\
(.033)\end{array}$ & $\begin{array}{l}-.063 \\
(.045)\end{array}$ \\
\hline$\Delta B i d A s k_{t}$ & $\begin{array}{l}.001 \\
(.002)\end{array}$ & $\begin{array}{l}.002 \\
(.003)\end{array}$ \\
\hline$\Delta T S_{t}$ & $\begin{array}{l}.042 \\
(.023)^{*}\end{array}$ & $\begin{array}{c}.100 \\
(.036)^{* * *}\end{array}$ \\
\hline$\Delta R_{t}^{10 y}$ & $\begin{array}{c}-.125 \\
(.024)^{* * *}\end{array}$ & $\begin{array}{c}-.306 \\
(.036)^{* * *}\end{array}$ \\
\hline$\hat{\sigma}^{2}$ & $\begin{array}{l}.016 \\
(.017)\end{array}$ & $\begin{array}{l}-.023 \\
(.013)^{*}\end{array}$ \\
\hline$\alpha$ & $\begin{array}{c}.348 \\
(.057)^{* * *}\end{array}$ & $\begin{array}{c}.468 \\
(.103)^{* * *}\end{array}$ \\
\hline$\beta$ & $\begin{array}{c}.537 \\
(.096)^{* * *}\end{array}$ & $\begin{array}{c}.622 \\
(.135)^{* * *}\end{array}$ \\
\hline$\omega$ & $\begin{array}{l}.000 \\
(.000)^{*}\end{array}$ & $\begin{array}{l}.000 \\
(.000)\end{array}$ \\
\hline $\mathrm{df}$ & $\begin{array}{l}4.414 \\
(.398)^{* * *}\end{array}$ & $\begin{array}{c}2.780 \\
(.165)^{* * *}\end{array}$ \\
\hline Obs. & 2307 & 2302 \\
\hline
\end{tabular}

Notes: The sample period is September $1^{\text {st }}, 2000$, until December $31^{\text {th }}, 2010$. The numbers in parentheses are observed information matrix standard errors.

${ }^{*} p<0.10,{ }^{* *} p<0.05,{ }^{* * *} p<0.01$. 


\section{Conclusions}

This paper has investigated the impact of the SNB bond purchase program of 2009-2010 on Swiss bond spreads, and found evidence in favor of an effect of the program on the credit spreads of covered bonds in the order of about 10 basis points. The effect materialized in the days following the announcement of the program and first bond purchases. No further effects of the subsequent actual bond purchases were found. Moreover, there was no evidence in the data of an effect of the program on corporate bond spreads. Finally, the unannounced bond sales in 2010 did not affect the spreads of the bond categories that were sold off. Markets were not aware of the sales until they were largely over, and the bonds were sold off during a period of low risk aversion and high demand for bonds.

The design of the empirical investigation allows us to plausibly identify the effect on covered spreads in the days after announcement as market participants discounting an expected portfolio balance effect of the SNB bond purchases. We interpret this effect as a lower bound for the total possible effect of the bond purchase program on bond yields. We cannot exclude that the subsequent actual bond purchases had further portfolio balance effects on spreads beyond those we identify, if, for example, such effects materialized with a delay of more than a few days, of if the effects on spreads were irregular or differed across purchases. The data and our empirical strategy does not allow us to pick up such delayed or irregular effects. We also cannot exclude that possible reverse causality conceals an impact of the actual purchases on spreads. In addition, the bond purchase program could have had signaling effects on expected future policy and short term interest rates. Signalling effects would not appear in the spreads we investigate, but rather in yields directly. The data we use does not allow us to identify such effects.

The findings suggest more generally that central bank asset purchases programs are perceived by the market as having portfolio balance effects, whether or not such portfolio balance mechanisms really are active. These expected effects are then discounted in the prices of the purchased assets at announcement and/or at the onset of the purchase program, depending on the level of information offered at the announcement of the program. One implication is that the way in which bond purchase programs and their exit are announced and communicated is central to the effect the central bank achieves. 


\section{References}

Avramov, D., G. Jostova, and A. Philipov, "Understanding changes in corporate credit spreads," Financial Analysts Journal, 2007, 63 (2), 90-105.

Bauer, Michael D. and Glenn D. Rudebusch, "The Signaling Channel for Federal Reserve Bond Purchases," Federal Reserve Bank of San Francisco Working Paper Series, No. 21, 2011.

Christensen, J. and G. Rudebusch, "The Response of Interest Rates to US and UK Quantitative Easing," The Economic Journal, 2012, 122, 385-414.

Cochrane, John H, "The Return of the Liquidity Effect: A Study of the Short-run Relation between Money Growth and Interest Rates," Journal of Business 83 Economic Statistics, 1989, 7 (1), 75-83.

Collin-Dufresne, P., R.S. Goldstein, and J.S. Martin, "The determinants of credit spread changes," The Journal of Finance, 2001, 56 (6), 2177-2207.

Fama, E.F. and K.R. French, "Business Conditions and Expected Returns on Stocks and Bonds," Journal of Financial Economics, 1989, 25 (1), 23-49.

Fleming, M.J., "Measuring Treasury Market Liquidity," FRBNY Economic Policy Review, September 2003.

Gagnon, Joseph, Matthew Raskin, Julie Remache, and Brian Sack, "The Financial Market Effects of the Federal Reserve's Large-Scale Asset Purchases," International Journal of Central Banking, March 2011, pp. 3-43.

Hamilton, James D. and Jing (Cynthia) Wu, "The Effectiveness of Alternative Monetary Policy Tools in a Zero Lower Bound Environment," Journal of Money, Credit and Banking, 2012, 44, 3-46.

Joyce, M., A. Lasoasa, I. Stevens, and M. Tong, "The financial market impact of quantitative easing in the UK," International Journal of Central Banking, 2011, 7.

Krogstrup, Signe, Samuel Reynard, and Barbara Sutter, "Liquidity effects at the Zero Lower Bound," SNB Working Paper, 2012, (2).

Manganelli, Simone, "The impact of the securities market programme," ECB RESEARCH BULLETIN, 2012, 17.

Neely, Christopher J., "The large scale asset purchases had large international effects," Working Papers 2010-018, Federal Reserve Bank of St. Louis 2010.

Stoll, H.R., "The Pricing of Security Dealer Services: An Empirical Study of Nasdaq Stocks," Journal of Finance, 1978, 33 (4), 1153-1172.

Stroebel, Johannes C. and John B. Taylor, "Estimated Impact of the Feds MortgageBacked Securities Purchase Program," International Journal of Central Banking, 2012, 8, $1-42$. 
Tobin, James, "The theory of portfolio selection," in Hahn and Brechling (eds.): The theory of interest rates, 1965, pp. 3-52.

Vayanos, Dimitri and Jean-Luc Vila, "A Preferred-Habitat Model of the Term Structure of Interest Rates," NBER Working Papers 15487, National Bureau of Economic Research, Inc 2009 . 
7 Appendix 
Table 8: Data

\begin{tabular}{|c|c|}
\hline Acronym & Explanation \\
\hline$c i_{t}$ & $\begin{array}{l}\text { Credit index total. Average emissions-weighted spread } \\
\text { of yields of all bonds with initial emissions volumes in } \\
\text { excess of CHF } 100 \text { mill, over same-maturity Confeder- } \\
\text { ation bond yield. Data collected daily between } 9 \text { and } \\
\text { 11am. Source: SNB }\end{array}$ \\
\hline$c i_{t}^{i n d}$ & $\begin{array}{l}\text { Same as credit index, but restricted to contain only } \\
\text { non-bank corporate issuers. Source: SNB. }\end{array}$ \\
\hline$c i_{t}^{p f}$ & $\begin{array}{l}\text { Same as credit index, but restricted to contain only } \\
\text { covered bonds (pfandbriefe). Source: SNB. }\end{array}$ \\
\hline$B i d A s k_{t}^{p f}$ & $\begin{array}{l}\text { Average emissions-weighted bid-ask spread for covered } \\
\text { bonds less that for confederation bonds. SNB-internal } \\
\text { computations. }\end{array}$ \\
\hline$B i d A s k_{t}^{i n d}$ & $\begin{array}{l}\text { Average emissions-weighted bid-ask spread for non- } \\
\text { bank corporate bonds less that for confederation } \\
\text { bonds. SNB-internal computations. }\end{array}$ \\
\hline $\operatorname{CorpH} L_{t}^{j}$ & $\begin{array}{l}\text { Spread between BBB and AAA rated corporate debt, } \\
j=E U, U S \text {.(BOFA Merrill Lynch, Datastream) }\end{array}$ \\
\hline$D_{t}^{i}$ & $\begin{array}{l}\text { Dummy for the date of the first purchases of bonds } i \text {, } \\
i=\text { covered, corporate. }\end{array}$ \\
\hline LibTois $_{t}$ & $\begin{array}{l}\text { Spread between Swiss } 3 \mathrm{M} \text { Libor and TOIS. } 3 \mathrm{M} \text { Li- } \\
\text { bor is collected daily at } 11 \mathrm{am} \text { in London (12am in } \\
\text { Zurich). TOIS is collected at } 11 \mathrm{am} \text { in Zurich. Source: } \\
\text { SNB }\end{array}$ \\
\hline Mat $_{t}$ & $\begin{array}{l}\text { Mean time-to-maturity of outstanding bonds. Based } \\
\text { on bond data collected daily between } 9 \text { and } 11 \text { am. } \\
\text { Source: SNB }\end{array}$ \\
\hline$R_{t}^{10 y}$ & $\begin{array}{l}\text { Zero coupon yield on 10-year government bond (Con- } \\
\text { federation bond). Based on bond data collected daily } \\
\text { between } 9 \text { and 11am. Source: SNB. }\end{array}$ \\
\hline$S N B b_{t}$ & $\begin{array}{l}\text { Cumulated purchases of bonds by the SNB, market } \\
\text { value, in percent of emissions volume. Source: SNB }\end{array}$ \\
\hline$S N B b_{t}^{i n d}$ & $\begin{array}{l}\text { Cumulated purchases of non-bank corporate bonds by } \\
\text { the SNB, market value, in percent of corporate emis- } \\
\text { sions volume. Source: SNB. }\end{array}$ \\
\hline$S N B b_{t}^{p f}$ & $\begin{array}{l}\text { Cumulated purchases of covered bonds by the SNB, } \\
\text { market value, in percent of covered emissions volume. } \\
\text { Source: SNB. }\end{array}$ \\
\hline$S P I_{t}$ & $\begin{array}{l}\text { Total returns on the Swiss Performance Index. Col- } \\
\text { lected daily at market close. Source: SNB. }\end{array}$ \\
\hline$T S_{t}$ & $\begin{array}{l}\text { Term spread between } 10 \text { year zero coupon yields } \\
\text { on government bonds and } 3 \text {-month CHF Libor rate. } \\
\text { Based on data collected between 9am and 11am daily. } \\
\text { Source: SNB. }\end{array}$ \\
\hline vol $_{t}$ & $\begin{array}{l}\text { Conditional volatiBBy of the SPI, } G A R C H(1,1) \text {. } \\
\text { Based on data collected daily at market close. SNB } \\
\text { internal calculations. Source: SNB. }\end{array}$ \\
\hline
\end{tabular}




\section{Communications}

P.0. Box, $\mathrm{CH}-8022$ Zurich

\section{Monetary policy assessment of 12 March 2009}

\section{Swiss National Bank takes decisive action to forcefully relax monetary conditions}

The economic situation has deteriorated sharply since last December, and there is a risk of negative inflation over the next three years. Decisive action is thus called for, to forcefully relax monetary conditions. Against this background, the Swiss National Bank (SNB) is making another interest rate cut and acting to prevent any further appreciation of the Swiss franc against the euro. To this end, it will increase liquidity substantially by engaging in additional repo operations, buying Swiss franc bonds issued by private sector borrowers and purchasing foreign currency on the foreign exchange markets.

The SNB is lowering the target range for the three-month Libor by 25 basis points, narrowing it to $0-0.75 \%$, with immediate effect. It will use all means at its disposal to gradually bring the Libor down to the lower end of the new target range, i.e. to approximately $0.25 \%$. Thus, the Libor now has a narrower target range of 75 basis points, compared with 100 previously.

With these exceptional measures, the SNB is helping to cushion the effects of the economic and financial crisis, with the aim of limiting the risk of deflation. The SNB has a mandate to ensure price stability, while taking economic developments into account. This objective encompasses the prevention of both deflation and inflation. In carrying out its mandate, the National Bank will - as it has in the past - base its decisions on an inflation forecast.

The fourth quarter of 2008 saw a sharp slowdown in the world economy, which affected all countries simultaneously. There is every reason to believe that the deterioration has continued over the past two months. The Swiss economy is being hit hard by these developments, and they are affecting nearly all sectors of the economy. The export industry is bearing the brunt, however. As a result, the SNB is revising its GDP growth forecast downwards for the year under review. It now expects real GDP to fall by between $2.5 \%$ and $3 \%$. 
The rapid deterioration in the economic situation and the decline in commodity prices have also led to a clear downward revision of the inflation forecast. Average annual inflation will amount to $-0.5 \%$ in 2009 . With the measures decided today, the SNB is forecasting average annual inflation for the following two years of virtually zero.

This inflation outlook calls for decisive action on the part of the SNB. By once again lowering the three-month Libor target range and acting to prevent any further appreciation of the Swiss franc against the euro, the SNB is seeking to counter the risk of deflation and of a dramatic deterioration in the economy.

\section{Global economic outlook}

Economic activity has declined sharply in the U.S., where consumption and exports have plummeted. The European economy has also undergone a significant contraction. The Asian economies, far from remaining unscathed by these developments, have also been heavily affected. The crisis that started in the financial markets of developed countries has spilled over to the real economy and is now impacting on the entire global economy. Against this background, the SNB has made a substantial downward revision to its growth forecasts for the major economies in 2009.

\section{Swiss economic outlook}

In Switzerland too, the economic situation has experienced a clear and rapid deterioration over the last six months. In the fourth quarter of 2008 , real GDP dropped by $1.2 \%$ in annualised terms. While the contraction in economic activity appeared to be less pronounced in Switzerland than in the major European countries, this figure nevertheless obscures the extent of the collapse in global demand, in particular in the manufacturing industry, with the concomitant sharp drop in exports. Expenditure on equipment investment was cut significantly. Construction investment also saw negative growth, resulting in a significant decline in final demand.

The magnitude of the contraction in demand in the fourth quarter of 2008 was unexpected. The result was an involuntary swelling of inventories, which contributed artificially to growth in GDP. This phenomenon is likely to reverse in the first quarter of this year. Consequently, the SNB expects an increased contraction in GDP in early 2009.

Unemployment has begun to grow again since September 2008, a trend that will continue in the months ahead. The resulting climate of uncertainty will prompt households to exercise more caution and will lead to a slowdown in consumer spending. In addition, weak global demand is likely to weigh on Swiss exports, which will force companies to defer or reconsider their investment plans. By contrast, favourable financing conditions will probably continue to support investment in residential construction. Moreover, public spending will play a countercyclical role. Due to the deepening of the global recession, the SNB is now forecasting a contraction in GDP of between $2.5 \%$ and $3 \%$ for this year. 


\section{Changes in monetary and financial conditions}

The SNB lowered the Libor target range decisively by 225 basis points over the course of the fourth quarter of last year. This monetary policy impetus will continue to feed through progressively to the economy. Short-term interest rates have dropped, and the interest rate curve has steepened. However, capital market risk premia have risen substantially since the collapse of Lehman Brothers, hampering the transmission of monetary policy stimuli. This is prompting the SNB to purchase Swiss franc bonds issued by private sector borrowers in order to bring about a relaxation of conditions on the capital markets.

The value of the Swiss franc has increased substantially since the beginning of the financial crisis in August 2007. This currency development has gained momentum since the National Bank's last assessment in December. Under the present circumstances, this represents an inappropriate tightening of monetary conditions. In view of this development, the SNB has decided to purchase foreign currency on the foreign exchange market, to prevent any further appreciation of the Swiss franc against the euro.

While $M 1$ and $M 2$ are registering strong growth rates, that of M3 remains moderate. In contrast, the monetary base almost doubled in one year. This development reflected the SNB's efforts to provide the interbank market with sufficient liquidity - as a response to the huge increase in the demand for liquidity brought about by the prevailing climate of uncertainty. If this demand had not been satisfied, the result would have been an undesirable rise in interest rates.

Since the beginning of 2008, the SNB has been conducting a qualitative survey with twenty banks which make up the bulk of the domestic loan market. The survey carried out in January 2009 shows that some banks have tightened their lending conditions slightly. Moreover, a growing number of banks are expecting to do so in the near future. While the statistics confirm lower growth in overall lending, they do not show an actual decline. Mortgage lending has remained unaffected by this development. The rate of growth in this area has risen since November, reaching $3.8 \%$ in January. It is too soon to tell whether this is an effect linked to the lowering of the three-month Libor, as has been observed in the past. By contrast, the growth rate in other loans has dropped sharply. It stood at $5.8 \%$ in January, compared with $20 \%$ a year earlier. In this category, lending is strongly cyclical and related to developments in the economy. The other loans, therefore, should decline in the near future. Overall, developments on the Swiss lending market have not followed the pattern observed abroad.

\section{Inflation and inflation risks}

After reaching a peak of $3.1 \%$ last July, inflation dropped back to $0.2 \%$ in February. This is attributable to the spectacular drop in the oil price from USD 145 to around USD 40 a barrel during the same period, as well as the appreciation of the Swiss franc. Inflation will continue to fall and will enter negative territory in the course of 2009. This is due to the prices of imported goods and services, in particular oil. They will be lower this year 
compared with last year's elevated levels. By contrast, inflation in domestic goods and services, despite weakening during the year, will remain positive in 2009.

For 2010 and 2011, inflation will remain very close to zero, because output will be below potential and unemployment will be high. Should the economy deteriorate more severely than expected, there would be a risk of negative inflation.

\section{Monetary policy decision}

A prolonged period of negative inflation is not compatible with the objective of maintaining medium-term price stability. Any tightening of monetary conditions is inappropriate in this depressed environment. By once again lowering the three-month Libor target range to $0-0.75 \%$, by gradually bringing the Libor down to the lower end of this range, i.e. to around $0.25 \%$, and by acting to prevent a further appreciation of the Swiss franc against the euro, the SNB is pursuing its expansionary monetary policy in order to support economic activity and limit the risk of deflation. The temporary narrowing of the Libor target range, which now stands at 75 basis points compared with the usual 100 basis points, is due to the fact that a negative Libor is not technically possible.

\section{Inflation forecast chart}

While the previous forecast (dash-dotted green curve) was based on the assumption that the three-month Libor would remain unchanged at $0.5 \%$, the new curve is based on a Libor of $0.25 \%$. It shows strongly negative inflation in 2009 . This is, in essence, attributable to movements in the price of oil (base effect). In 2010 and 2011, inflation will remain very low, despite a Libor of $0.25 \%$. This is due to the unfavourable economic outlook. Inflation will increase slightly at the end of 2011. This slight uptick in inflation is explained by the fact that a Libor of $0.25 \%$ does not represent an equilibrium level capable of guaranteeing price stability in the longer term. 
Inflation forecast of December 2008 with Libor at $0.50 \%$ and of March 2009 with Libor at $0.25 \%$

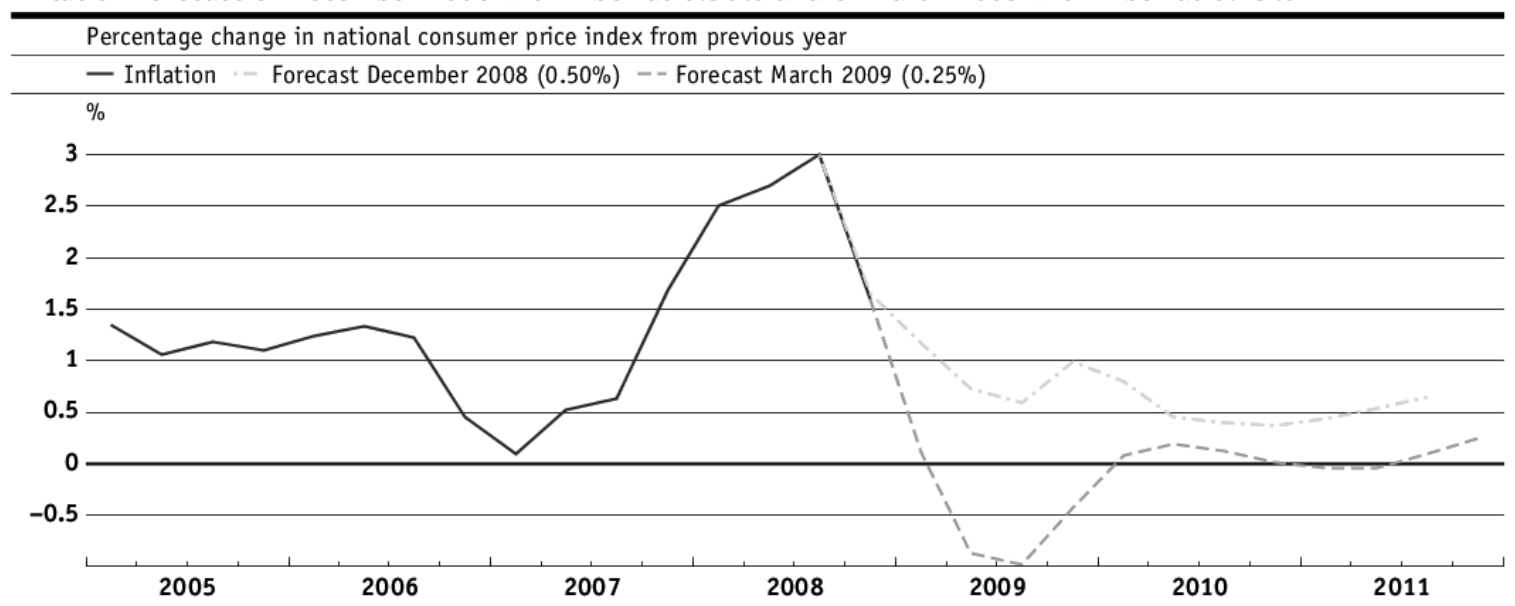

Observed inflation March 2009

\begin{tabular}{|c|c|c|c|c|c|c|c|c|c|c|c|c|c|c|c|c|c|c|c|c|}
\hline & $\mid \begin{array}{r}2005 \\
01\end{array}$ & Q2 & 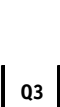 & Q4 & $\mid \begin{array}{c}2006 \\
01\end{array}$ & Q2 & Q3 & Q4 & $\mid \begin{array}{l}2007 \\
01\end{array}$ & & Q3 & Q4 & $\mid \begin{array}{c}2008 \\
01\end{array}$ & Q2 & Q3 & Q4 & 2005 & 2006 & 2007 & 2008 \\
\hline Inflation & 1.35 & 1.06 & 1.18 & 1.10 & 1.23 & 1.33 & 1.22 & 0.46 & 0.09 & 0.52 & 0.63 & 1.68 & 2.50 & $2.70 \quad 3$ & 3.00 & 1.60 & 1.2 & 1.1 & 0.7 & 2.5 \\
\hline
\end{tabular}

Inflation forecast of December 2008 with Libor at $0.50 \%$ and of March 2009 with Libor at $0.25 \%$

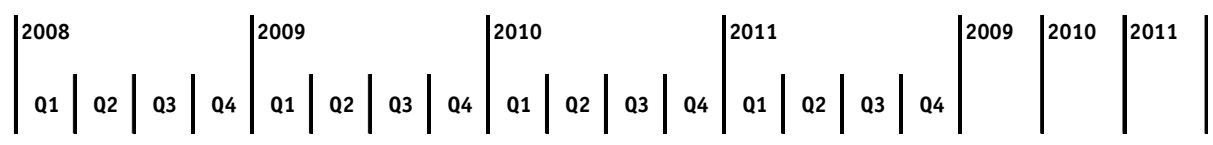




\section{Swiss National Bank Working Papers published since 2004:}

2004-1 Samuel Reynard: Financial Market Participation and the Apparent Instability of Money Demand

2004-2 Urs W. Birchler and Diana Hancock: What Does the Yield on Subordinated Bank Debt Measure?

2005-1 Hasan Bakhshi, Hashmat Khan and Barbara Rudolf: The Phillips curve under state-dependent pricing

2005-2 Andreas M. Fischer: On the Inadequacy of Newswire Reports for Empirical Research on Foreign Exchange Interventions

2006-1 Andreas M. Fischer: Measuring Income Elasticity for Swiss Money Demand: What do the Cantons say about Financial Innovation?

2006-2 Charlotte Christiansen and Angelo Ranaldo: Realized Bond-Stock Correlation: Macroeconomic Announcement Effects

2006-3 Martin Brown and Christian Zehnder: Credit Reporting, Relationship Banking, and Loan Repayment

2006-4 Hansjörg Lehmann and Michael Manz: The Exposure of Swiss Banks to Macroeconomic Shocks - an Empirical Investigation

2006-5 Katrin Assenmacher-Wesche and Stefan Gerlach: Money Growth, Output Gaps and Inflation at Low and High Frequency: Spectral Estimates for Switzerland

2006-6 Marlene Amstad and Andreas M. Fischer: Time-Varying Pass-Through from Import Prices to Consumer Prices: Evidence from an Event Study with Real-Time Data

2006-7 Samuel Reynard: Money and the Great Disinflation

2006-8 Urs W. Birchler and Matteo Facchinetti: Can bank supervisors rely on market data? A critical assessment from a Swiss perspective

2006-9 Petra Gerlach-Kristen: A Two-Pillar Phillips Curve for Switzerland

2006-10 Kevin J. Fox and Mathias Zurlinden: On Understanding Sources of Growth and Output Gaps for Switzerland

2006-11 Angelo Ranaldo: Intraday Market Dynamics Around Public Information Arrivals

2007-1 Andreas M. Fischer, Gulzina Isakova and Ulan Termechikov: Do FX traders in Bishkek have similar perceptions to their London colleagues? Survey evidence of market practitioners' views 
2007-2 Ibrahim Chowdhury and Andreas Schabert: Federal Reserve Policy viewed through a Money Supply Lens

2007-3 Angelo Ranaldo: Segmentation and Time-of-Day Patterns in Foreign Exchange Markets

2007-4 Jürg M. Blum: Why `Basel II’ May Need a Leverage Ratio Restriction

2007-5 Samuel Reynard: Maintaining Low Inflation: Money, Interest Rates, and Policy Stance

2007-6 Rina Rosenblatt-Wisch: Loss Aversion in Aggregate Macroeconomic Time Series

2007-7 Martin Brown, Maria Rueda Maurer, Tamara Pak and Nurlanbek Tynaev: Banking Sector Reform and Interest Rates in Transition Economies: Bank-Level Evidence from Kyrgyzstan

2007-8 Hans-Jürg Büttler: An Orthogonal Polynomial Approach to Estimate the Term Structure of Interest Rates

2007-9 Raphael Auer: The Colonial Origins Of Comparative Development: Comment. A Solution to the Settler Mortality Debate

2007-10 Franziska Bignasca and Enzo Rossi: Applying the Hirose-Kamada filter to Swiss data: Output gap and exchange rate pass-through estimates

2007-11 Angelo Ranaldo and Enzo Rossi: The reaction of asset markets to Swiss National Bank communication

2007-12 Lukas Burkhard and Andreas M. Fischer: Communicating Policy Options at the Zero Bound

2007-13 Katrin Assenmacher-Wesche, Stefan Gerlach, and Toshitaka Sekine: Monetary Factors and Inflation in Japan

2007-14 Jean-Marc Natal and Nicolas Stoffels: Globalization, markups and the natural rate of interest

2007-15 Martin Brown, Tullio Jappelli and Marco Pagano: Information Sharing and Credit: Firm-Level Evidence from Transition Countries

2007-16 Andreas M. Fischer, Matthias Lutz and Manuel Wälti: Who Prices Locally? Survey Evidence of Swiss Exporters

2007-17 Angelo Ranaldo and Paul Söderlind: Safe Haven Currencies 
2008-1 Martin Brown and Christian Zehnder: The Emergence of Information Sharing in Credit Markets

2008-2 Yvan Lengwiler and Carlos Lenz: Intelligible Factors for the Yield Curve

2008-3 Katrin Assenmacher-Wesche and M. Hashem Pesaran: Forecasting the Swiss Economy Using VECX* Models: An Exercise in Forecast Combination Across Models and Observation Windows

2008-4 Maria Clara Rueda Maurer: Foreign bank entry, institutional development and credit access: firm-level evidence from 22 transition countries

2008-5 Marlene Amstad and Andreas M. Fischer: Are Weekly Inflation Forecasts Informative?

2008-6 Raphael Auer and Thomas Chaney: Cost Pass Through in a Competitive Model of Pricing-to-Market

2008-7 Martin Brown, Armin Falk and Ernst Fehr: Competition and Relational Contracts: The Role of Unemployment as a Disciplinary Device

2008-8 Raphael Auer: The Colonial and Geographic Origins of Comparative Development

2008-9 Andreas M. Fischer and Angelo Ranaldo: Does FOMC News Increase Global FX Trading?

2008-10 Charlotte Christiansen and Angelo Ranaldo: Extreme Coexceedances in New EU Member States' Stock Markets

2008-11 Barbara Rudolf and Mathias Zurlinden: Measuring capital stocks and capital services in Switzerland

2008-12 Philip Sauré: How to Use Industrial Policy to Sustain Trade Agreements

2008-13 Thomas Bolli and Mathias Zurlinden: Measuring growth of labour quality and the quality-adjusted unemployment rate in Switzerland

2008-14 Samuel Reynard: What Drives the Swiss Franc?

2008-15 Daniel Kaufmann: Price-Setting Behaviour in Switzerland - Evidence from CPI Micro Data

2008-16 Katrin Assenmacher-Wesche and Stefan Gerlach: Financial Structure and the Impact of Monetary Policy on Asset Prices

2008-17 Ernst Fehr, Martin Brown and Christian Zehnder: On Reputation: A Microfoundation of Contract Enforcement and Price Rigidity 
2008-18 Raphael Auer and Andreas M. Fischer: The Effect of Low-Wage Import Competition on U.S. Inflationary Pressure

2008-19 Christian Beer, Steven Ongena and Marcel Peter: Borrowing in Foreign Currency: Austrian Households as Carry Traders

2009-1 Thomas Bolli and Mathias Zurlinden: Measurement of labor quality growth caused by unobservable characteristics

2009-2 Martin Brown, Steven Ongena and Pinar Yeșin: Foreign Currency Borrowing by Small Firms

2009-3 Matteo Bonato, Massimiliano Caporin and Angelo Ranaldo: Forecasting realized (co)variances with a block structure Wishart autoregressive model

2009-4 Paul Söderlind: Inflation Risk Premia and Survey Evidence on Macroeconomic Uncertainty

2009-5 Christian Hott: Explaining House Price Fluctuations

2009-6 Sarah M. Lein and Eva Köberl: Capacity Utilisation, Constraints and Price Adjustments under the Microscope

2009-7 Philipp Haene and Andy Sturm: Optimal Central Counterparty Risk Management

2009-8 Christian Hott: Banks and Real Estate Prices

2009-9 Terhi Jokipii and Alistair Milne: Bank Capital Buffer and Risk Adjustment Decisions

2009-10 Philip Sauré: Bounded Love of Variety and Patterns of Trade

2009-11 Nicole Allenspach: Banking and Transparency: Is More Information Always Better?

2009-12 Philip Sauré and Hosny Zoabi: Effects of Trade on Female Labor Force Participation

2009-13 Barbara Rudolf and Mathias Zurlinden: Productivity and economic growth in Switzerland 1991-2005

2009-14 Sébastien Kraenzlin and Martin Schlegel: Bidding Behavior in the SNB's Repo Auctions

2009-15 Martin Schlegel and Sébastien Kraenzlin: Demand for Reserves and the Central Bank's Management of Interest Rates

2009-16 Carlos Lenz and Marcel Savioz: Monetary determinants of the Swiss franc 
2010-1 Charlotte Christiansen, Angelo Ranaldo and Paul Söderlind: The Time-Varying Systematic Risk of Carry Trade Strategies

2010-2 Daniel Kaufmann: The Timing of Price Changes and the Role of Heterogeneity

2010-3 Loriano Mancini, Angelo Ranaldo and Jan Wrampelmeyer: Liquidity in the Foreign Exchange Market: Measurement, Commonality, and Risk Premiums

2010-4 Samuel Reynard and Andreas Schabert: Modeling Monetary Policy

2010-5 Pierre Monnin and Terhi Jokipii: The Impact of Banking Sector Stability on the Real Economy

2010-6 Sébastien Kraenzlin and Thomas Nellen: Daytime is money

2010-7 Philip Sauré: Overreporting 0il Reserves

2010-8 Elizabeth Steiner: Estimating a stock-flow model for the Swiss housing market

2010-9 Martin Brown, Steven Ongena, Alexander Popov, and Pinar Yeșin: Who Needs Credit and Who Gets Credit in Eastern Europe?

2010-10 Jean-Pierre Danthine and André Kurmann: The Business Cycle Implications of Reciprocity in Labor Relations

2010-11 Thomas Nitschka: Momentum in stock market returns: Implications for risk premia on foreign currencies

2010-12 Petra Gerlach-Kristen and Barbara Rudolf: Macroeconomic and interest rate volatility under alternative monetary operating procedures

2010-13 Raphael Auer: Consumer Heterogeneity and the Impact of Trade Liberalization: How Representative is the Representative Agent Framework?

2010-14 Tommaso Mancini Griffoli and Angelo Ranaldo: Limits to arbitrage during the crisis: funding liquidity constraints and covered interest parity

2010-15 Jean-Marc Natal: Monetary Policy Response to Oil Price Shocks

2010-16 Kathrin Degen and Andreas M. Fischer: Immigration and Swiss House Prices

2010-17 Andreas M. Fischer: Immigration and large banknotes

2010-18 Raphael Auer: Are Imports from Rich Nations Deskilling Emerging Economies? Human Capital and the Dynamic Effects of Trade 
2010-19 Jean-Pierre Danthine and John B. Donaldson: Executive Compensation: A General Equilibrium Perspective

2011-1 Thorsten Beck and Martin Brown: Which Households Use Banks? Evidence from the Transition Economies

2011-2 Martin Brown, Karolin Kirschenmann and Steven Ongena: Foreign Currency Loans Demand or Supply Driven?

2011-3 Victoria Galsband and Thomas Nitschka: Foreign currency returns and systematic risks

2011-4 Francis Breedon and Angelo Ranaldo: Intraday patterns in FX returns and order flow

2011-5 Basil Guggenheim, Sébastien Kraenzlin and Silvio Schumacher: Exploring an uncharted market: Evidence on the unsecured Swiss franc money market

2011-6 Pamela Hall: Is there any evidence of a Greenspan put?

2011-7 Daniel Kaufmann and Sarah Lein: Sectoral Inflation Dynamics, Idiosyncratic Shocks and Monetary Policy

2011-8 Iva Cecchin: Mortgage Rate Pass-Through in Switzerland

2011-9 Raphael A. Auer, Kathrin Degen and Andreas M. Fischer: Low-Wage Import Competition, Inflationary Pressure, and Industry Dynamics in Europe

2011-10 Raphael A. Auer and Philip Sauré: Spatial Competition in Quality, Demand-Induced Innovation, and Schumpeterian Growth

2011-11 Massimiliano Caporin , Angelo Ranaldo and Paolo Santucci de Magistris: On the Predictability of Stock Prices: a Case for High and Low Prices

2011-12 Jürg Mägerle and Thomas Nellen: Interoperability between central counterparties

2011-13 Sylvia Kaufmann: K-state switching models with endogenous transition distributions

2011-14 Sébastien Kraenzlin and Benedikt von Scarpatetti: Bargaining Power in the Repo Market

2012-01 Raphael A. Auer: Exchange Rate Pass-Through, Domestic Competition, and Inflation: Evidence from the 2005/08 Revaluation of the Renminbi

2012-02 Signe Krogstrup, Samuel Reynard and Barbara Sutter: Liquidity Effects of Quantitative Easing on Long-Term Interest Rates 
2012-03 Matteo Bonato, Massimiliano Caporin and Angelo Ranaldo: Risk spillovers in international equity portfolios

2012-04 Thomas Nitschka: Banking sectors' international interconnectedness: Implications for consumption risk sharing in Europe

2012-05 Martin Brown, Steven Ongena and Pinar Yeşin: Information Asymmetry and Foreign Currency Borrowing by Small Firms

2012-06 Philip Sauré and Hosny Zoabi: Retirement Age across Countries: The Role of Occupations

2012-07 Christian Hott and Terhi Jokipii: Housing Bubbles and Interest Rates

2012-08 Romain Baeriswyl and Camille Cornand: Reducing overreaction to central bank's disclosures: theory and experiment

2012-09 Bo E. Honoré, Daniel Kaufmann and Sarah Lein: Asymmetries in Price-Setting Behavior: New Microeconometric Evidence from Switzerland

2012-10 Thomas Nitschka: Global and country-specific business cycle risk in time-varying excess returns on asset markets

2012-11 Raphael A. Auer, Thomas Chaney and Philip Sauré: Quality Pricing-to-Market

2012-12 Sébastien Kraenzlin and Thomas Nellen: Access policy and money market segmentation

2012-13 Andreas Kropf and Philip Sauré: Fixed Costs per Shipment

2012-14 Raphael A. Auer and Raphael S. Schoenle: Market Structure and Exchange Rate Pass-Through

2012-15 Raphael A. Auer: What Drives Target2 Balances? Evidence From a Panel Analysis

2012-16 Katja Drechsel and Rolf Scheufele: Bottom-up or Direct? Forecasting German GDP in a Data-rich Environment

2013-01 Andreas Kettemann and Signe Krogstrup: Portfolio balance effects of the SNB's bond purchase program 
Swiss National Bank Working Papers are also available at www.snb.ch, section Publications/Research Subscriptions or individual issues can be ordered at Swiss National Bank, Fraumünsterstrasse 8, CH-8022 Zurich, fax +41 4463181 14, E-mail library@snb.ch 